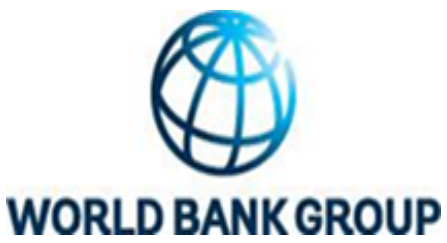

\title{
Potential Responses to the COVID-19 Outbreak in Support of Migrant Workers ${ }^{1}$
}

\author{
“Living Paper” Version 8 (May 26, 2020)
}

This note describes the key challenges facing the health, livelihoods, and mobility of internal and international migrants and their families due to the COVID-19 outbreak. The note presents the policy options available to governments to address these challenges and describes the assistance that the World Bank can offer in areas related to social protection and jobs to support these efforts.

\section{KEY TAKEAWAYS}

- The living and working conditions of internal and international migrants make them vulnerable to contracting COVID-19.

- Measures put in place to control disease transmission both within and across countries have resulted in significant disruption in transportation networks and in labor markets that have hit migrant workers hard. The resulting decline in remittances will transmit these negative impacts to the families of migrants.

- Travel restrictions may lead to labor shortages in critical sectors like agriculture that are dominated by migrant workers.

- While the specific type of support that should be targeted to migrants depends on location, legal status, and type of migration, most migrants will need access to safety nets in the form of cash or in-kind assistance to support them as they comply with transmission control measures and cope with the impacts of the crisis. Policies to support employment retention and promotion will be particularly important as a complement to these safety nets for internal migrants and migrants returning from abroad. Policies to offset the expected declines in remittances will be important for all migrants and their families.

- Programs created to respond to the COVID-19 outbreak should be migrant-sensitive to take into account the unique challenges facing migrants.

\footnotetext{
1 This note was prepared by Harry Moroz, Maheshwor Shrestha, and Mauro Testaverde, World Bank Social Protection and Jobs Unit, with inputs from Pablo Acosta, Samik Adhikari, Syud Amer Ahmed, Jumana Alaref, Shrayana Bhattacharya, Laurent Bossavie, Carole Chartouni, Luc Christiaensen, Carlo Corazza, Helen Dempster, Dung Doan, Matthew Dornan, Puja Vasudeva Dutta, Francesco Fasani, Daniel Garrote Sanchez, Yashodan Ghorpade, Hayden Hubbard, Yang Huan, Su Su Htay, Keiko Inoue, Johannen Koettl, Manjula Luthria, Froilan Malit Jr., Alessandra Marini, Mushfiq Mobarak, Simona Moscarelli, Harish Natarajan, JJ Naddeo, Philip O’Keefe, Junko Onishi, Caglar Ozden, Ekaterina Pankratova, Ioanna Pantelaiou, Kenia Parson, Boban Varghese Paul, Josefina Posadas, Ririn Salwa Purnamasari, Dilip Ratha, Nayib Rivera, Achim Schmillen, Rebekah Smith, Lars Sondergaard, Nithin Umapathi, Dewen Wang, Ruslan Yemtsov, Soonwha Yi, and Wei Zhang.
} 
Across the globe, international migrants and their families are highly exposed to the COVID19 pandemic and its impacts. Based on estimates of migration stocks and remittances, before the pandemic around 270 million people lived outside their country of birth and sent nearly $\$ 700$ billion in remittances to their home countries. As of mid-May, the 20 countries with the most cases of COVID19 host 55 percent of the world's migrants who send home 54 percent of the world's remittances (Figure 1).

Migrant health is a key concern during the COVID-19 outbreak. Although migrants tend to be younger than the local population, they tend to live and work in crowded conditions that do not permit social distancing, putting them at increased risk of contracting the disease (Kluge et al. 2020). This has occurred in Singapore where an estimated 40 percent of the country COVID-19 cases in midApril were low-skilled foreign workers and in Saudi Arabia where more than half of the cases were foreigners. ${ }^{i}$ Migrants also face challenges accessing healthcare even in normal circumstances due to lack of health insurance, cost, administrative hurdles, lack of access to facilities, and language barriers. In the United States, for example, 20 percent of immigrants lacked health insurance in 2017 versus 7 percent of locals (Batalova, Blizzard, and Bolter 2020). Additionally, many migrants are frontline workers who keep people healthy, safe, and fed. These workers may be at less risk of job loss but are at greater risk of contracting COVID-19. The Migration Policy Institute estimates that 17 percent of workers employed in frontline occupations in the United States are migrants (MPI 2020). In Switzerland, 47 percent of doctors and 32 percent of nurses are foreign-born.ii Finally, migrants returning home, particularly because of job loss or travel restrictions, can be vectors for the disease, as has happened in the case of Myanmar migrants returning home from Thailand.iii

Restrictions on travel and the related fall in commercial flights, also put migrants at risk. Major migration destinations from the United States (a destination for migrants from Central America) to Australia (a destination for migrants from the Pacific Islands) to Russia (a destination for migrants from Central Asia) have closed their borders to international travelers (Figure 2). In some cases such as Nepal, significant migrant origins have closed their borders to returning migrants. ${ }^{\text {iv }}$ Some countries including China have imposed restrictions on travel within countries. At the same time, international and domestic travel options have dwindled. This has left migrants in a variety of challenging situations. Migrants who work in or were planning to work in another location cannot access their job (as is occurring with migrants from Tajikistan to Russia), cannot travel home even if they have lost their job (as is occurring with migrants from Cambodia, Lao PDR, and Myanmar in Thailand), or are stuck in transit (as has occurred with internal migrants in India).

Even amid significant unemployment, travel restrictions, transmission control measures, and fear of contracting COVID-19 are creating labor shortages in some sectors. Travel restrictions mean that migrant workers from Eastern Europe find it difficult to access the agriculture sector in Britain, France, Germany, and Spain.v Farmers are warning that without these workers they will struggle to harvest spring and summer crops. ${ }^{\text {vi }}$ The potential for labor shortages in the agricultural sector is also apparent in Poland, where Ukrainian migrants have returned homevii; in the United States, which relies on seasonal workers primarily from Mexicoviii; and in India, where the agricultural sector of some states relies on migrants from elsewhere in Indiaix.

Migrants are likely to experience severe economic impacts from the COVID-19 outbreak. Migrants account for a large share of the workforce in the sectors that are most likely to be affected by the severe job loss resulting from the crisis. The UN estimates that nearly 30 percent of the workforce in highly affected sectors in OECD countries is foreign-born (UN 2020). In Spain, 20 
percent of services and sales workers, who primarily work in the retail sectors that are suffering from the economic impacts of the outbreak, are foreign-born. $x$ This figure is 19 percent in Italy, 18 percent in Germany, and 14 percent in France and the United Kingdom (Box 1 presents a short review of studies present estimates of vulnerability of migrant workers). The negative effects of job loss can be particularly significant for migrant workers because they frequently work in informal jobs and so lack safety nets in case of job loss or illness. Few migrants from developing countries have access to social protection coverage (Avato, Koettl, and Sabates-Wheeler 2010). There is evidence that households do not expect migration to be a viable path for employment in the near future. For example, Listening to the Citizens of Uzbekistan survey found that the number of respondents with household members considering seasonal migration fell by more than 95 percent over the previous year (World Bank 2020c).

\section{Box 1: Estimates of the vulnerability of migrant workers}

Several studies have investigated the vulnerability of migrant workers to the health and job impacts of the COVID-19 outbreak. These studies generally look at the prevalence of migrant workers in two types of jobs that are likely to be affected by the COVID-19 outbreak: 1) jobs in essential industries and occupations in which workers are unlikely to face job loss but are more likely to face health risks; and 2) jobs in non-essential industries and occupations that cannot be done from home in which workers are likely to face job loss.

- Garrote-Sanchez et al. (2020), a draft note produced by the World Bank, creates several measures of labor market exposure to the COVID-19 outbreak in the European Union based on whether someone works in an essential sector, whether they can do their job from home, and whether their job involves face-to-face interactions. Migrants, particularly migrants from outside of the EU, are found to be overrepresented in jobs that are exposed to COVID-19-related job losses.

- Fasani and Mazza (2020) uses guidelines from the European Commission and the Dutch government to define key occupations during the COVID-19 crisis and investigate the prevalence of "EU mobile citizens" and "Extra-EU migrants" in these occupations. Thirteen percent of key workers are immigrants (either "EU mobile citizens" or "Extra-EU migrants"). This varies from near zero in Easter European countries to around 20 percent in Western European countries like Italy, Belgium, and Germany. The prominence of foreign-born workers is more apparent in certain key occupations, such as cleaners and helpers and laborers in mining and construction.

- Gelatt (2020) looks at the prevalence of migrants in industries that are essential (e.g. health care) and in industries that hard-hit (e.g. hotels and restaurants) by the COVID-19 outbreak in the United States. Migrant workers are overrepresented in both industry types.

- CMS (2020) uses the US Department of Homeland Security's definition of "essential critical infrastructure" categories to estimate that 69 percent of all immigrants in the labor force and 74 percent of all undocumented workers are essential infrastructure workers compared to 65 percent of the local labor force.

Source: Authors. 
Figure 1: Share of global migrants and global remittances in the 20 countries with the most cases of COVID-19 as of early April 2020

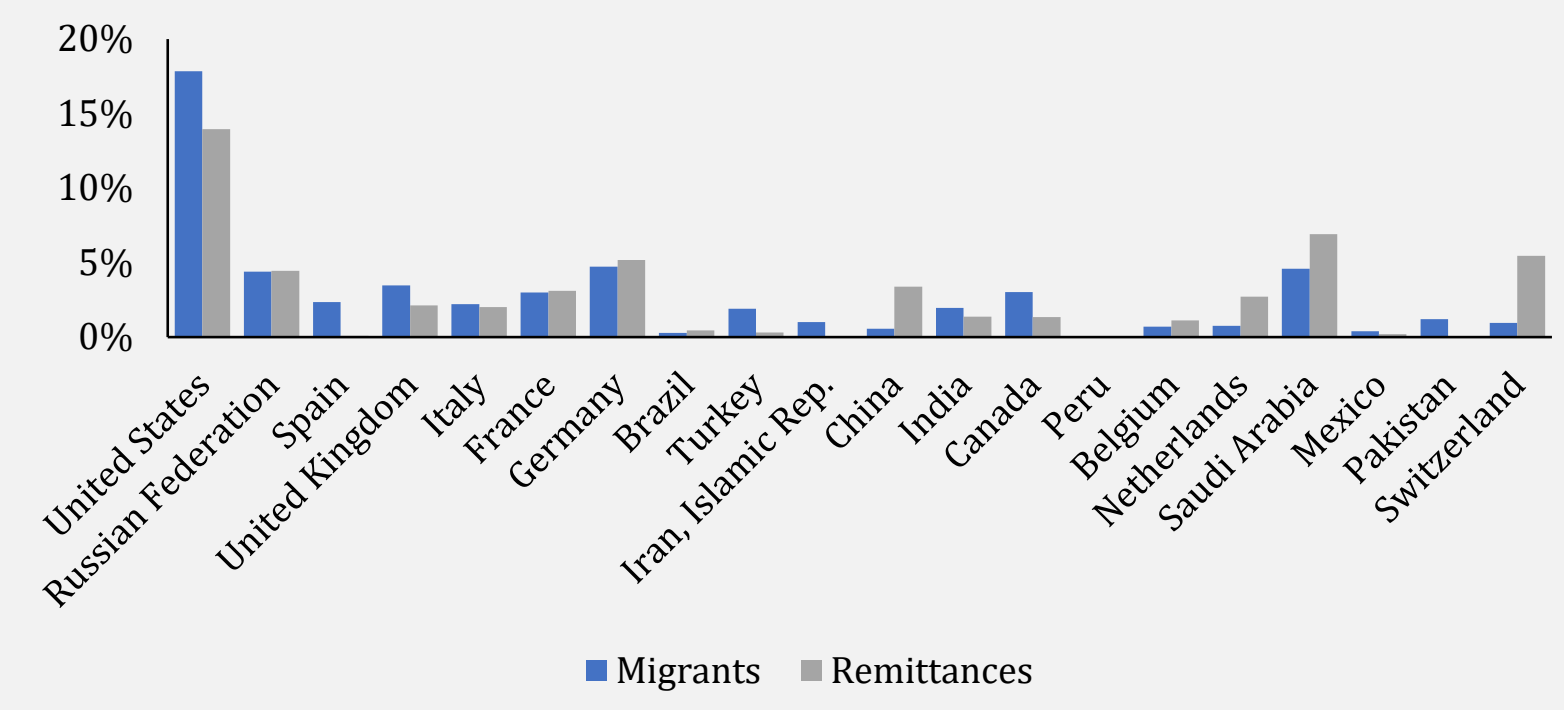

Note: Remittance data is not available for Iran or Peru.

Source: World Bank; Johns Hopkins University.

Figure 2: Travel restrictions around the world as of early April 2020

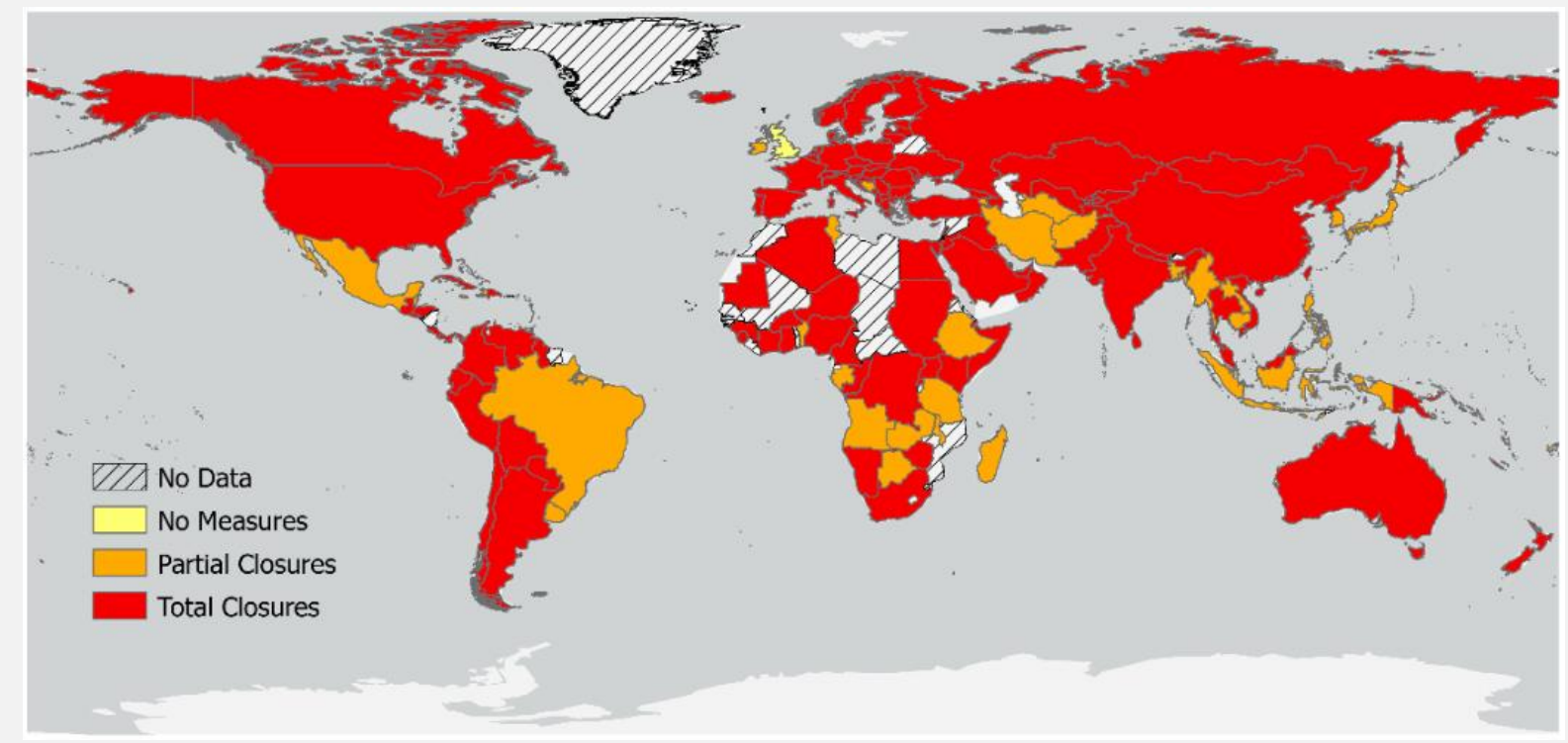

Source: IOM; Hale et al. (2020).

The negative impacts of migrants losing their jobs have an additional, global effect on migrants' families and their home countries. The drop in labor income from job loss as a result of the COVID-19 outbreak will result in significant declines in the remittances that families throughout the world rely on to make ends meet and to make investments in human capital and businesses. The World Bank estimates that remittances to low- and middle-income countries will drop by around 20 
percent in 2020 (World Bank 2020d). Drops are forecasted to be largest in Europe and Central Asia, the Middle East and North Africa, and Latin America and the Caribbean. Remittances represent a significant source of income in many developing countries. For example, the ratio of remittances to GDP is greater than 4 percent in fourteen countries in Sub-Saharan Africa, putting them at risk when migrants lose their jobs (World Bank 2020b). Remittances flows to Lesotho where remittances represent 15.7 percent of GDP and to Zimbabwe where they represent 8 percent of GDP would be particularly affected by a downturn in South Africa. In Nigeria, where remittances amount to 6 percent of GDP, the Central Bank recorded a drop of inflows by half in Februaryxi.

Internal migrants will be affected in similar ways. Internal migration is a fact of life for households across the globe. The IOM estimates that there are 763 million internal migrants globally. Dense living and working conditions make internal migrants susceptible to contracting COVID-19. Restrictions on internal travel and the fall in domestic commercial transportation options resulting from the COVID19 outbreak have put many migrants in limbo, unable to return home but unable to make a living in their destination. This situation has arisen in India, which announced a lockdown that restricted business activity and movement. Many internal migrants lost jobs and were left without income, food, and accommodation; others sought to return home but have been stranded in transit due to travel restrictions. This situation has also arisen in China and Sri Lanka. The economic impacts of the COVID-19 outbreak for internal migrants and their families are likely to be significant. In Africa, for example, large numbers of rural youth are employed in urban areas: 35 percent of Kenyan households, 30 percent of Senegalese households, and 42 percent of households from Uganda have at least one internal migrant. These young people will no longer be able to earn a living to support their family due to lockdowns.

The longer-term impacts of the COVID-19 outbreak on migration are uncertain. Several factors could play a role. Persistently depressed economic conditions could mean lower demand for migrant workers and less support for permissive migration policies. Prolonged travel restrictions may induce additional technological progress in sectors like agriculture where shortages do arise, also lowering demand for migrant workers (Clemens, Lewis, and Postel 2018). On the other hand, technological progress is unlikely to be able to completely automate away the need for migrant workers, and a sustained recovery is likely to rely on this labor to fill shortages that arise as economies recover. Negative attitudes have been already been expressed towards internal migrants in some settings, which could have implications for movements within countries in the future (IOM 2020). Greater focus may also need to be placed on the often dense working and living conditions of migrants.

\section{CHALLENGES}

Different types of migrants face different challenges. The COVID-19 outbreak will create some challenges that are common to all people who have moved across internal and international borders. However, there are some unique challenges that specific types of migrants - temporary, informal, permanent, internal, and returning migrants - face. Table $\mathbf{1}$ at the end of this section summarizes the challenges faced by these different types of migrants.

The COVID-19 outbreak poses specific challenges for temporary migrants and their employers. These workers migrate temporarily (even seasonally) with work visas. Immigration status is almost always linked to maintaining a job often with a single employer. These workers tend to be employed in low-skilled occupations and remit large shares of their income. Social protection for these workers, if received at all, is typically limited to some work injury compensation or health benefits, and almost never includes unemployment assistance. Job loss as a result of the COVID-19 outbreak means loss of income for consumption, to remit home, and to repay the often large loans 
taken out to finance migration. Job loss may even result in loss of housing, as accommodations are often provided by employers. Shared accommodations and work environments that are not conducive to social distancing and home-based work make these workers more susceptible to COVID-19. Accessing medical care may be difficult because they often work and live in remote areas and may avoid testing and treatment due to low incomes. Beyond income and health effects, job loss could result in loss of legal status where this status is tied to employment. In some cases, such as for workers from Pacific Island Countries working in Australia and New Zealand, border closures create significant uncertainty for temporary migrant workers whose visas will expire, even in cases in which they are able to continue working.xii Lack of resources to pay for travel home and lack of travel options could put these migrants at significant legal risk. Even as demand for migrant workers declines in some sectors as a result of the COVID-19 outbreak, shortages are arising in other sectors in which temporary and seasonal migrants typically work but cannot access due to travel restrictions. This is occurring in the agricultural sector in Australia, France, New Zealand, and the United Kingdom.

These challenges are exacerbated for migrant workers who move abroad without legal documents. Informal migrant workers may have crossed borders to seek work in neighboring countries without legal authorization or may have entered legally but are not or are no longer authorized to work. Estimates suggest that up to 20 percent of all migrants could be irregular (UNDESA 2018). Regional migration hubs like India, Malaysia, Russia, South Africa, Thailand, Russia host more than 25 million migrants and are the origin of more than 5 percent of global remittances (UNDESA 2019; World Bank 2020). Long, porous borders with lower income neighbors mean that many of these migrants move without the necessary legal documents. Overstay is more common in high-income countries like the United States. Most informal migrants are employed in jobs without social protection benefits, contracts, and workplace protections, or are ineligible for these benefits because they lack migration documents. This makes it easy for firms to fire them during economic downturns and more vulnerable once they have lost their jobs.

Legal long-term international migrants are likely better positioned to weather the COVID-19 outbreak, but face challenges including ones that are relevant for households back home. These are migrant workers who have a path to permanent residency in the destination countries. Most of these migrants are in destinations in the global north such as Australia, Canada, the European Union, the United Kingdom, and United States. Even if they do not intend to return home, many send remittances. These migrants typically have secure employment (for many, secure employment offers a pathway to residency), and may have access to social insurance and social assistance measures. The impact of the COVID-19 outbreak on this group is likely to be similar to that on local workers with both experience significant negative economic effects. However, there are several potential additional issues that this group could face. Job loss associated with the COVID-19 outbreak could jeopardize a migrant's legal status (particularly for those with employment-linked legal status). This group may not be eligible for some social protection measures, as is the case with the cash transfers currently being deployed in the United States. Finally, temporary or permanent income loss could lead to a reduction in remittances sent home.

Internal migrants also face significant challenges from the COVID-19 outbreak. Internal migrants in developing countries tend to be employed in low-paying, hazardous, and informal jobs with limited access to health services, social protection coverage, or worker protections. This makes it easy for firms to fire them during economic downturns and more vulnerable once they have lost their jobs. Job loss may lead to loss of accommodations where employers provide housing. Workers facing loss of wage income often seek out employment in the agricultural sector. However, lack of resources combined with travel restrictions can make a return home from wage employment in 
urban areas impossible. Internal migrants may also lack access to benefits if these are based on location or jurisdiction and are not portable.

Table 1: The challenges faced by different types of migrants

\begin{tabular}{|c|c|c|}
\hline Category & Examples & Challenges \\
\hline $\begin{array}{l}\text { Temporary } \\
\text { international } \\
\text { migrants }\end{array}$ & $\begin{array}{l}\text { Most are in Gulf Cooperation Council } \\
\text { countries and Malaysia through } \\
\text { bilateral migration agreements with } \\
\text { many countries in South and South- } \\
\text { East Asia. } \\
\text { - Other examples include Korea's } \\
\text { Employment Permit System and the } \\
\text { guest and seasonal worker programs } \\
\text { in the United States, Australia, and } \\
\text { New Zealand }\end{array}$ & $\begin{array}{l}\text { - Job loss leads to economic hardship, loss } \\
\text { of remittances for migrant's family, } \\
\text { inability to repay debt incurred to } \\
\text { finance migration, loss of employer- } \\
\text { provided housing, and legal status } \\
\text { - Limited social protection } \\
\text { - High risk of disease exposure and } \\
\text { transmission due to living and working } \\
\text { conditions } \\
\text { - Lack of resources and travel restrictions } \\
\text { may strand these workers who may not } \\
\text { receive final pay if they have lost their } \\
\text { job }\end{array}$ \\
\hline $\begin{array}{l}\text { Informal } \\
\text { international } \\
\text { migrants }\end{array}$ & $\begin{array}{l}\text { Origin and destination countries with } \\
\text { long, porous borders (India, Malaysia, } \\
\text { Russia, South Africa, Thailand, United } \\
\text { States) } \\
\text { - High-income countries where } \\
\text { migrants may overstay visas (Europe, } \\
\text { United States) }\end{array}$ & $\begin{array}{l}\text { - Same as temporary international } \\
\text { migrants but these migrants also } \\
\text { typically lack contracts and any social } \\
\text { protection benefits }\end{array}$ \\
\hline $\begin{array}{l}\text { Long-term } \\
\text { international } \\
\text { migrants }\end{array}$ & $\begin{array}{l}\text { High-income countries (Australia, } \\
\text { Canada, European Union, United } \\
\text { Kingdom, United States) }\end{array}$ & $\begin{array}{l}\text { - Job loss could jeopardize legal status } \\
\text { - May not be eligible for certain types of } \\
\text { social protection } \\
\text { - Job loss may lead to a reduction in } \\
\text { remittances }\end{array}$ \\
\hline $\begin{array}{l}\text { Internal } \\
\text { migrants }\end{array}$ & - Many developing countries & $\begin{array}{l}\text { - Same as temporary international } \\
\text { migrants without the implications for } \\
\text { legal status in most cases } \\
\text { - May face challenges accessing benefits if } \\
\text { they are based on location or jurisdiction }\end{array}$ \\
\hline $\begin{array}{l}\text { Return } \\
\text { migrants }\end{array}$ & - Many developing countries & $\begin{array}{l}\text { Health risks for migrants moving in } \\
\text { large groups and for populations at } \\
\text { home } \\
\text { When back home, lack of employment } \\
\text { opportunities, limited access to social } \\
\text { safety nets, large debts accumulated to } \\
\text { finance migration costs, families that are } \\
\text { no longer receiving remittances }\end{array}$ \\
\hline
\end{tabular}

Migrants who have returned home as a result of the COVID-19 outbreak will continue to face challenges. The combination of the decline in economic activity, travel restrictions, and lack of social protection in many migrant hubs have already induced many migrants to seek to return home. As of late April 2020, more than 60,000 migrants had returned to Myanmar via official channels while total returns were likely more than 150,000 according to the Myanmar State Counselor (IOM 2020b). from Thailand with similar numbers returning to Cambodia and Lao PDR. More than 115,000 Afghan workers returned from Iran to Afghanistan during March 2020. xiii These movements create health risks for migrants moving in large groups and for populations back at home because of lack of 
screening at formal and informal border crossing and insufficient health care.xiv When back home, returnees will continue to face challenges including lack of employment opportunities, limited access to social safety nets, large debts accumulated to finance migration costs that would have been paid with higher incomes earned at the destination, families that are no longer receiving remittances, and even discrimination by community members fearful that migrants may transmit COVID-19.

\section{POTENTIAL ACTIVITIES IN SUPPORT OF MIGRANTS}

Several mechanisms can be used to provide support to migrants in response to the COVID-19 outbreak. These mechanisms include 1) social safety nets to protect migrants from the negative consequences of the COVID-19 outbreak including income loss and health impacts; 2) employment retention policies to keep all workers, including migrant workers, employed; 3) employment promotion policies to help displaced migrant workers get back to work; and 4) remittance policies to address the fall in remittances that is likely to result from the COVID-19 outbreak. These programs can be targeted directly to migrants or, if they are targeted to a broader population, be made sensitive to migrants' needs. This will help ensure that everyone has access to the benefits and services needed to help stop the spread of the pandemic and limit its negative consequences. Table 2 at the end of this section summarizes these potential responses, while Annex 1 presents interventions implemented in various countries.

1) Social safety nets. Social assistance or social safety nets provide direct support either in the form of cash or in-kind goods and services to smooth consumption, compensate for higher prices, and help prevent falls into poverty. Governments could consider three different strategies to address the current challenges.

First, eligibility for existing safety net programs can be expanded to address the challenges faced by migrants. For instance, Australia has expanded the categories of migrants who can access the Special Benefit financial assistance program for people in severe financial hardship, but only for certain categories of migrant workers (and not Pacific Island workers under the Seasonal Worker Program or the Pacific Labor Scheme). Portugal has granted immigrants and asylum seekers whose applications are being processed temporary residency rights, which gives them access to public services such as national health services and welfare benefits. ${ }^{x v}$ France extended residence permits for 3 months to ensure that access to health care and social security is not interrupted.xvi

Second, programs newly created to address the economic shock of COVID-19 can be targeted regardless of migration status. For instance, migrant workers holding residence permits in Italy can apply for the €600 income subsidy under the COVID-19 Cure Italy stimulus. The same applies to migrants in Ireland, who have access to the $€ 350$ weekly Pandemic Unemployment Payment. International seasonal migrant workers under the Recognized Seasonal Employer program are eligible for New Zealand's COVID-19 sick leave scheme as well as for government funding under the COVID-19 Economic Response Package in case they cannot work during the lockdown because their employer's business is not operating or if the employer cannot afford to pay them due to reduced business activity. Australia also announced that it would allow unemployed individuals on temporary work visas to withdraw up to $\$ 5,996$ (A $\$ 10,000)$ from their superannuation (retirement) savings annually for the next two years. When the scheme was first announced in response to COVID19, only individuals eligible for unemployment benefits had been allowed to access the scheme, excluding individuals on temporary work visas. In Myanmar, an emergency COVID-19 cash transfer targeted to vulnerable groups, including internal and returning international migrants, will be financed by a consortium of international donors. Foreign workers in Uzbekistan are eligible for the training that will be provided as part of an anti-crisis fund. Brazil, Thailand, and Vietnam have 
announced benefits for informal and self-employed workers that would apply to workers regardless of their location (that is, internal migrants can access the benefits). China's response measures to COVID-19 including temporary assistance have largely treated internal migrants and non-migrants equally. India is considering a similar approach.

Third, new programs can be created to help migrants confront the specific challenges they face. These include providing access to testing and treatment, providing food and accommodations, providing transportation assistance, and providing cash grants.

- Provide access to free or low-cost testing and treatment for COVID-19. Migrants face an increased risk of contracting COVID-19 and have significant challenges accessing healthcare. In response, governments can provide access to free or low-cost testing and treatment for COVID-19 regardless of migration status. Countries welcoming returning migrants home can provide the same. Qatar is providing medical services including medical checkups for coronavirus and quarantine services free of cost, and has announced that full salaries will be provided by employers to migrant workers in quarantine or treatment, and has set aside funds to support companies.xvii Additionally, a hotline to report grievances via text messages was launched for migrant workers in their language. Temporary migrants in Kazakhstan have access to free medical clinics for COVID-19. In the United Kingdom, the National Health Service is free and accessible for coronavirus regardless of migration status. xviii Korea has made access to free COVID-testing and treatment available to informal foreign workers, along with partial income support during treatment. Hospitals are not mandated to ask about a migrant's status or report their details to immigration and labor authorities. Saudi Arabia provides testing and medical treatment free of charge for all COVID 19 infection cases irrespective on nationality.

- Provide food and accommodations for displaced migrant workers. Job loss particularly among internal migrants working day-to-day as casual laborers can result in immediate food needs. Loss of a job can also mean loss of accommodations when housing is provided by an employer. Travel restrictions that strand migrants may also create immediate needs for food and shelter. In these cases, government can provide food assistance and housing subsidies or housing alternatives. Government may also need to consider how support can be provided to migrants in cramped living conditions like labor camps (IOM 2020). The Government of Panama announced that will be offered to around 2,500 migrants at three immigration stations at Panama's borders with Colombia and Costa Rica. Singapore temporarily provided $\$ 35$ a day in housing support to assist with employers' costs due to Malaysia-imposed restrictions preventing frequent commuter workers from returning to Malaysia.xix This assistance has now been stopped.xx $\mathbf{Q}$ atar has said that workers unable to return home if their jobs are terminated will be able to remain "with proper lodging and food." xxi

- Arrange transportation or provide transportation subsidies to help migrants return home. Health concerns and job loss mean that many migrants want to return home. Travel restrictions, cost, and lack of commercial transportation options complicate efforts to return, leaving some migrants stranded at their destination or in some cases in transit. Government assistance can help these migrants return home by financing transportation subsidies in cases in which commercial transportation options are available and arranging transportation in cases in which commercial options are not available. These may require coordination between origin and host governments. Indonesia's National Agency for Placement and Protection of Indonesian Migrant Workers (BNP2TKI) has facilitated the return of documented and undocumented migrants from Malaysia. In China, local government have 
fully or partially provided costs for "point-to-point" chartered buses, trains, and flights to transport internal migrant workers from their hometowns to workplaces.

- Provide cash grants to migrant workers to compensate them for income loss and provide debt relief. The economic impacts of COVID-19 on the labor market mean that migrant workers may be left with less income or without an income source at all. Governments can help protects workers in this situation by providing cash transfers to workers to (partially) compensate them for income loss and to provide debt relief. The State of California in the United States announced the introduction of a one-time cash benefit of $\$ 500$ in support of undocumented Californians impacted by COVID-19 who are ineligible for unemployment insurance benefits and disaster relief due to their immigration status. China has provided a one-off cash transfer of $\$ 423$ to internal migrant workers in Wuhan unable to return to employment in other locations because of travel restrictions. The Philippines has announced $\$ 200$ cash assistance to international migrants workers whose work has been affected by COVID-19 regardless of whether they are abroad or in the Philippines.xxii Thailand has made $\$ 456$ available to returning Thai migrants who are members of the Overseas Workers Fund.xxiii This assistance will not be available to undocumented migrants.

2) Employment retention. Employers can be incentivized to maintain their existing workforce either through deductions in social insurance contributions or through employment subsidies. These policies can cover the entire workforce, but be implemented with the intention to prevent the displacement of migrant workers, particularly internal migrant workers. Singapore recently announced cancellations of the foreign workers levies due by employers in April. China has provided social insurance exemptions and wage subsidies to stabilize employment including for internal migrant workers. In Korea, foreign workers under the Employment Permit System are eligible for fiscal measures to support SMEs enacted in response to the COVID-19 outbreak, including employment retention subsidies and paid leave subsidies. Employment retention policies can also involve changes to migration regulations, particularly in sectors facing shortages such as health care and agriculture. Korea has extended the employment contracts of temporary foreign workers in its Employment Permit System (EPS) by 50 days for workers whose employment terms are ending soon. The United Kingdom automatically extended the visas of foreign doctors for one year.xiv Extensions to work permits were also introduced in Australia, Bahrain, Hong Kong, Italy, Japan, New Zealand, Poland, Spain and the UK.

3) Employment promotion. Employment promotion policies help jobseekers find jobs and employers find workers. These policies also include rules regarding migration programs that can be adjusted to facilitate employment. Some of these policies are immediately relevant, particularly due to shortages created by travel restrictions, while others will be most relevant at later stages of the response to COVID-19 when social distancing and transmission control policies are relaxed.

- Deploy employment services to promote employment among migrant workers. Employment services like job matching and job search programs can help migrant workers who are displaced by the crisis find jobs, particularly to fill labor market gaps created by travel restrictions. The programs could also provide transportation or transportation subsidies for migrant workers to facilitate access to jobs in the agricultural sector where shortages may develop. This may require incorporating health checks to protect against transmission of COVID-19. Such programs could also provide safe transport to migrant workers to jobs in the agricultural sector. Australia is seeking to match temporary migrant workers participating in the Pacific Labor Scheme with new employers where existing employment has ceased as a result of the crisis. China has developed a job application and 
held online job fairs, interviews, and recruitments to help match workers, including internal migrants unable to travel to their workplaces, to jobs. ${ }^{\mathrm{xxv}}$ Responding to the inability to bring new temporary migrant workers into the country, Korea is seeking to attract existing migrants to work in agriculture by setting up agriculture job-matching centers close to farmers. Job matching and job search programs can also be targeted to migrants returning from abroad who are jobless, but may have skills learned from working abroad that could be deployed in local labor markets.

- Ensure that migration regulations meet the needs of migrants and employers. Regulations regarding migration programs can be adjusted to ensure that labor market needs can be met including by lengthening visas for existing workers and facilitating new admissions (MPI 2020b). Germany lifted a ban it had imposed on seasonal agricultural workers entering the country. ${ }^{x x v i}$ Farmers will be able to bring in 80,000 workers in April and May. The seasonal workers will arrive by plane, receive a health check, and be required to be separated from local workers for two weeks. In its EPS temporary migration program, Korea relaxed regulations on sector of employment for temporary migrants to allow them to work in agriculture, and has permitted visiting family members to seek seasonal agriculture jobs. In Spain, it was recently announced that work permits will be provided to young immigrants who arrived in Spain as unaccompanied minors and who have now turned 18 and have residency but not work permits. Canada created an exception to restrictions on international travel by specifically allowing temporary workers to enter Canada and stay after a 14-day isolation period. Korea has also extended the job search period for migrant workers seeking to change jobs. New Zealand has extended the duration of temporary work, student, visitor, limited, or interim visas due to expire between April 2 and July 9, including work permits for seasonal workers from the Pacific under the Recognized Seasonal Employer scheme. Australia has allowed Pacific islanders under the Seasonal Worker Program and Pacific Labor Scheme to extend their visas for up to 12 months, while also relaxing employment rules for those employed in agriculture under the Working Holiday Maker visa. Australia has also allowed seasonal workers to change employer. Vietnam has proposed easing its COVID-19related restrictions on international entry to allow high-skilled foreign nationals to enter the country because of a shortage of qualified replacements. ${ }^{x x v i i}$

- Other employment promotion policies. Several other employment promotion policies can be considered, particularly for internal migrants. Public works could help address the significant unemployment that is likely to result from the COVID-19 outbreak. In the short term, a public works program could be adapted to address immediate needs associated with controlling the transmission of COVID-19 (e.g. assistance with contact tracing, at testing sites, with transmission control). In the longer term as transmission concerns become less significant, more traditional public works programs could be deployed incorporating appropriate health and safety measures. China has created such jobs for migrants who are temporarily unable to go to their job sites. Significant job loss, particularly in certain sectors like the services and tourism, creates an opportunity to upskill and reskill idle workers for jobs in sectors likely to rebound as the COVID-19 outbreak is controlled. Such training could be provided in the form of e-learning where possible and could seek to reskill and upskill workers in sectors that were growing prior to the COVID-19 crisis. China has launched an online skills development program including for migrant workers.

4) Remittances. The COVID-19 outbreak is likely to have a significant impact on the ability of migrants to remit money. Remittances are a key channel of support for households throughout the world. The outbreak is also affecting the ability of remittance service providers to do business 
because of operational disruptions related to health risks and financial risks related to lack of liquidity. In Fiji, Samoa, and Tonga, for example, movement restrictions have limited the availability of remittance services. Finally, travel restrictions mean that physical delivery of remittances is not possible. To support the recovery of remittances in the short term, governments should classify remittance service providers as essential services that are permitted to operate despite transmission control measures given that they follow social distancing guidelines. Government should publicize in real time the location of branches, ATMs, and agents that are providing remittance services. Governments should also support the remittances industry with instruments to help it manage credit and liquidity risks. In the medium term, governments can promote digital models of remitting, support universal financial access, enhance payment systems, and help develop the regulatory capacity necessary to support these systems. xxviii Even with these measures, however, the success of economic stimulus efforts in developed economies and in net remitting countries will have a large impact on whether remittance flows recover in the medium term after the initial impacts of the COVID-19 outbreak. Qatar has undertaken measures related to remittances in response to the COVID-19 outbreak. Online remittances have been introduced to replace exchange houses with companies mandated to educate workers about online remittance services. Sri Lanka has exempted remittance flows from abroad from some regulations and taxes and Zimbabwe has permitted money transfer agencies to open 3 times a week (IOM 2020c). 
Table 2: Potential activities in support of migrants

\begin{tabular}{|c|c|c|c|c|c|c|}
\hline & Policy & $\begin{array}{l}\text { Temporary } \\
\text { international }\end{array}$ & $\begin{array}{c}\text { Informal } \\
\text { international }\end{array}$ & $\begin{array}{l}\text { Long-term } \\
\text { international }\end{array}$ & Internal & Return \\
\hline \multirow{7}{*}{ 1) } & Expand eligibility for existing safety net programs to migrants & $\mathrm{X}$ & $\mathrm{X}$ & $\mathrm{X}$ & $\mathrm{X}$ & $\mathrm{X}$ \\
\hline & Include migrants in safety net programs responding to COVID-19 & $\mathrm{X}$ & $\mathrm{X}$ & $\mathrm{X}$ & $\mathrm{X}$ & $\mathrm{X}$ \\
\hline & Provide access to free and low-cost testing and treatment & $\mathrm{X}$ & $\mathrm{X}$ & $\mathrm{X}$ & $\mathrm{X}$ & $\mathrm{X}$ \\
\hline & Provide food assistance & $\mathrm{X}$ & $\mathrm{X}$ & & $\mathrm{X}$ & $\mathrm{X}$ \\
\hline & Provide housing subsidies or alternative housing arrangements & $\mathrm{X}$ & $\mathrm{X}$ & & $\mathrm{X}$ & $\mathrm{X}$ \\
\hline & Provide transportation subsidies or transportation arrangements & $\mathrm{X}$ & $\mathrm{X}$ & & $\mathrm{X}$ & $\mathrm{X}$ \\
\hline & Provide cash grants & $\mathrm{X}$ & $\mathrm{X}$ & $\mathrm{X}$ & $\mathrm{X}$ & $\mathrm{X}$ \\
\hline \multirow{3}{*}{ 2) } & $\begin{array}{c}\text { Exempt, reduce, or defer social insurance contributions for } \\
\text { employers }\end{array}$ & $\mathrm{X}$ & $\mathrm{X}$ & $\mathrm{X}$ & $\mathrm{X}$ & \\
\hline & Provide employment subsidies to employers & $\mathrm{X}$ & $\mathrm{X}$ & $\mathrm{X}$ & $\mathrm{X}$ & $\mathrm{X}$ \\
\hline & Use migration regulations to protect employment & $\mathrm{X}$ & $\mathrm{X}$ & & & \\
\hline \multirow{4}{*}{ 3) } & Deploy job search, matching, and placement services & $\mathrm{X}$ & $\mathrm{X}$ & $\mathrm{X}$ & $\mathrm{X}$ & $\mathrm{X}$ \\
\hline & Adjust migration regulations to protect migrants and fill shortages & $\mathrm{X}$ & $\mathrm{X}$ & & & \\
\hline & Launch COVID-19-responsive public works & & & & $\mathrm{X}$ & $\mathrm{X}$ \\
\hline & Launch training programs leveraging e-learning where possible & & & & $\mathrm{X}$ & $\mathrm{X}$ \\
\hline \multirow{2}{*}{ 4) } & Classify remittance service providers (RSPs) as essential services & $\mathrm{X}$ & $\mathrm{X}$ & $\mathrm{X}$ & $\mathrm{X}$ & \\
\hline & Create instruments to help RSPs manage credit and liquidity risks & $\mathrm{X}$ & $\mathrm{X}$ & $\mathrm{X}$ & X & \\
\hline
\end{tabular}


Implementing these policies will require adapting to the special characteristics and needs of migrants. Policymakers will need to take into account the potential for mainstreaming, the challenges migrants face accessing services, and the unique challenge of targeting and delivering services to migrants.

Mainstreaming. Governments should seek to utilize existing programs to address the needs of migrants wherever possible. This recognizes that both migrants and locals will face significant disruptions due to the COVID-19 outbreak, will help ensure that all groups are provided protections against getting and transmitting the disease, will reduce administrative complexity, and will help allow migrants to access benefits more quickly.

Access. Migrants face significant challenges accessing social protection benefits that must be taken into account in responses to the COVID-19 outbreak (UNDESA 2018; Hopkins, Bastagli, and HagenZanker 2016). Formal restrictions at times exclude migrants from these benefits. Informal migrants who have not used legal channels for international migration are typically not eligible for benefits. Even legal migrants may be ineligible due to discretionary eligibility criteria such as requirements for property ownership or evidence of integration. In some countries, utilizing benefits has implications for renewal of residency permits or for family reunification. Such formal restrictions arise in the case of internal migrants as well due to population registration and residency requirements. Both internal and international migrants face other barriers to access social protection. Program registration and benefits claims procedures can be complex and require documentation that migrants may not have. Language barriers may also arise. These will be important considerations as policymaker consider creating new programs for migrants and making existing programs available to them.

Women migrants tend to be overrepresented in the informal economy and among undocumented workers, particularly given the prevalence of women in domestic work, and so may face greater challenges accessing support. The risk of violence against women may be increased during the pandemic, as domestic violence seems to increase during emergencies (ILO 2020c). However, access to support services for women facing violence may be challenging due to closures related to COVID19. These needs must be taken into account in designing responses to the COVID-19 outbreak. Overall, women migrants need access to safe spaces including with provision of hygiene and sanitation (ILO 2020; ILO 2020b).

Targeting. Targeting migrants for assistance requires identifying them. As for delivery of benefits generally, this is done more easily if migrants already appear in social registries. In the case of international migration, migrants who have migrated using legal channels ("formal migrants") are typically registered with destination country authorities. These migrants may also be listed on social registries via participation in health insurance, workplace injury, or other social protection schemes. These migrants may also be registered with source country authorities, whether in administrative databases or through instruments like migrant welfare funds, that can allow source countries to identify beneficiaries abroad for assistance (e.g. repatriation assistance).

Migrants who have not used legal channels ("informal migrants"), however, are unlikely to be registered with destination country authorities (though there are exceptions). Extending assistance to these migrants is more challenging, and will likely require innovative means of identifying beneficiaries including self-targeting (e.g. through the provision of free food or accommodation), selfenrollment (e.g. requesting potential beneficiaries to enroll themselves to receive benefits), or 
cooperation with telecommunications companies and remittance services providers (e.g. to identify phone numbers and/or bank accounts where benefits could be directed) (Box 2). Extending benefits to informal migrants will raise concern among them that identifying themselves to receive benefits could result in legal penalties and/or deportation. Assurances may need to be provided that registration and receipt of benefits will not have legal consequences.

\section{Box 2: Providing assistance to undocumented migrants during the COVID-19 outbreak}

Several countries have recognized and sought to address the vulnerabilities facing informal migrants. Even before the COVID-19 outbreak, informal migrants tended to live and work in precarious conditions without access to social protection. During the outbreak, their lack of documentation and legal status makes delivering support to them even more challenging. While some governments have excluded this population from their COVID-19 response programs, others have developed programs specifically targeted to them.

- Several subnational governments in the United States are working through nongovernmental organizations to provide support, including cash assistance, to undocumented workers. The State of California created a $\$ 125$ million relief fund for undocumented migrants with $\$ 75$ million in state support and $\$ 50$ million in donations. The fund will provide $\$ 500$ per adult to approximately 150,000 undocumented workers. The workers apply for the funds, which are to be disbursed via regional nonprofits with experience serving undocumented workers. The City of New York will use a \$20 million grant from the Open Society Foundation to provide one-time payments of $\$ 400$ per adult to migrant workers regardless of migration status via community-based organizations.

- Other countries have facilitated return home by reducing or eliminating penalties on undocumented migrants. Kuwait introduced a special amnesty for undocumented migrant workers from Bangladesh, and provided support for their return. The workers will be able to reenter Kuwait in the future. Korea has undertaken a similar measure exempting informal migrant workers who leave Korea voluntarily from penalties and allowing them to return in the future.

- In other cases, governments are making programs available to migrants regardless of migration status. Korea has made access to free COVID-19 testing and treatment available to undocumented foreign workers, along with partial income support during treatment. In the United States, undocumented migrants have access to city-created COVID-19 relief measures in the cities of Austin, Chicago, and Minneapolis.

- Origin country governments have a role to play as well. Indonesia, for instance, has facilitated the return of documented and undocumented migrants from Malaysia.

Source: Authors.

The process for identifying internal migrants for assistance is parallel to that for identifying international migrants. Where internal migrants appear on social registries, targeting will be easier. Where they do not, other methods like self-targeting, self-enrollment, or identification through telecommunications providers will be necessary. Thailand provides an example of a process for identifying informal internal migrant workers: beneficiaries outside of the social security system could be identified using their national ID, which can be linked to existing social assistance programs with benefits delivered via the e-payment system linked to their national ID.

Identifying migrants may also help policymakers detect where potential disease hotspots and areas of vulnerability could emerge. Returning migrants may be vectors for transmission of COVID-19. 
Additionally, areas that typically receive remittances from abroad may be particularly at risk from disruptions to these flows. Using administrative records on migration and return, data on remittance flows, and potentially big data sources such as cellphone records policymakers can identify where new outbreaks may emerge or where disruptions in migration patterns may make households more vulnerable (Mobarak 2020).

\section{Box 3: Using data on migration to fill gaps in testing capacity}

Many low- and middle-income countries lack the capacity to test for COVID-19. This, in turn, hinders the development and implementation of policy responses to target assistance to areas in need. Ahsan et al. (2020) develop an approach for assessing COVID-19 risk using migration data to make up for this deficiency. The approach is based on the observation that migration is a primary driver for the spread of disease across geographies. The methodology constructs an international COVID-19 exposure risk index using migration links and the prevalence of COVID-19 cases in migration destinations. This methodology is then extended using local data on airport disembarkations and a survey similar to the World Bank Living Standards Measurement Study (LSMS) survey to create subnational COVID-19 exposure risk indexes in Bangladesh and the Philippines. The authors validate the approach using actual COVID-19 case data and a telephone survey. The availability of the LSMS survey in many countries mean that the approach can be applied in many countries that may lack COVID-19 testing capacity.

Source: Ahsan et al. (2020).

Delivery. Delivery of assistance to migrants will need to take both the unique circumstances of migrants and public health into account. Any program to facilitate the access of migrants to labor markets facing shortages will require careful consideration of worker screening, social distancing while at work, and what to do and what benefits to provide in cases in which a worker falls ill (MPI $2020 \mathrm{~b}$ ). Accommodations may need to be provided to migrants in cases in which job loss also results in loss of housing. These accommodations will need to be adapted to comply with social distancing and transmission control measures. Where delivery of cash assistance is not possible and food aid is needed, delivery of this assistance will also need to take these measures into account (e.g. by adapting pre-existing food distribution systems to offer pre-packaged meals). In both cases, connections can be created to health services to help migrants in need of medical assistance and limit the spread of COVID-19. Overall, solutions to the challenges of distributing benefits may require a shift to greater reliance on digital and mobile transfers, spreading out disbursement dates and times, relying on alternative delivery means (e.g. helicopters or drones, government-provided services for those in quarantine), and many other adjustments.

Subnational governments. Local governments have an important role to play in filling gaps in national programs. These governments may understand the unique needs of their residents better than national governments and be able to create programs to address these local needs when action is not taken at the national level. Given the concentration of migrants in urban areas, action at the local level may be necessary to confront their unique challenges. The City of Minneapolis in the United States has created a forgivable loan program to help renters and small businesses regardless of migration and documentation status.xxix Also in the United States, the State of California has pledged to provide approximately 150,000 undocumented adult Californians with a one-time cash benefit of $\$ 500$ per adult with a cap of $\$ 1,000$ per household to deal with the specific needs arising from the COVID-19 pandemic. ${ }^{x \times x}$ This is in part a reaction to the ineligibility of this group for federal COVID-19 relief measures. In general, however, action at the local level should not replace comprehensive responses to the challenges faced by migrants by national governments. 
The World Bank has mobilized resources to assist and prioritize quick, decisive, and effective responses to the COVID-19 outbreak in two phases. The Phase One response is a $\$ 4$ billion facility primarily focused on health sector interventions, though support for vulnerable households can be considered as has been done, for example, in Pakistan and Tajikistan. Phase Two, which is under Board consideration, is a $\$ 150$ billion multisectoral facility to be rolled out for the next 15 months. The facility focuses on: 1) protecting the poor and vulnerable; 2) supporting businesses; and 3) strengthening economic resilience and the speed of recovery. These three pillars are aligned with the instruments described in this note. A full range of lending instruments (IPFs, DPFs, DPOs, PForRs) will be available to flexibly tailor responses to client needs. Just-in-time technical advisory services and analytical support can also be provided to help clients design and implement effective responses.

The SPJ GP is working closely with countries around the world to deploy social protection systems and programs to address the challenges faced by migrants during the COVID-19 outbreak. Countries such as China, Brazil, India, and the Philippines are building on their existing social protection platforms to provide safety nets, employment services, and social insurance to additional beneficiaries, including international and internal migrant workers. For example, in China households with unemployed members are now eligible to apply for Dibao and temporary social assistance. Brazil is following a similar approach to reach informal and self-employed workers, and the government of India is considering similar interventions with the financial support of the World Bank. By mobilizing financial resources and providing technical assistance, the World Bank team can support the expansion of current social protection systems to serve the migrant populations affected by the COVID-19 outbreak.

Prior to the crisis, the World Bank increasingly supported governments around the world on issues related to migration. During the past 18 years, the World Bank has implemented more than $\$ 750$ million of lending operations on migration of which almost $\$ 100$ million went to international migration. The World Bank provides financial and advisory services on labor mobility in 26 countries, and new requests emerge regularly. The topics covered by these projects include skills development, job search, recruitment and placement, access to social and public services in origin and destination countries, and protection of workers' rights (World Bank 2016).

Migration-related projects financed by the World Bank include elements that would be relevant to address the challenges faced by migrants during the COVID-19 outbreak and recovery. A number of World Bank-financed projects can provide ideas about potential interventions to provide immediate assistance and temporary safety nets to migrant workers, ensure reintegration and livelihoods restoration, and strengthen employability. The Emergency Repatriation and Livelihood Restoration for Migrant Workers Project in Bangladesh supported the Bangladeshi Government in: 1) repatriating its migrant workers who had fled conflict in Libya in a timely manner; and 2) providing a one-time cash grant as a transitional safety net measure to help the repatriated migrants meet immediate basic needs and commence the process of livelihood restoration. Though not designed to respond to a specific crisis, the Rural Migrant Skills Development and Employment Project in China is very relevant to the current situation because it addressed the vulnerabilities and limited economic opportunities of rural migrants. The project included activities related to skills development, employment services, and worker protection designed specifically for rural migrants. 


\section{References}

Ahsan, Reshad, Kazi Iqbal, Mahreen Khan, Ahmed Mushfiq Mobarak, and Abu Shonchoy. 2020. "Using Migration Patterns to Predict COVID-19 Risk Exposure in Development Countries." Yale School of Management.

Avato, Johanna, Johannes Koettl, and Rachel Sabates-Wheeler. 2010. "Social Security Regimes, Global Estimats, and Good Practices." World Development 38(4):455-66.

Batalova, Jeanne, Brittany Blizzard, and Jessica Bolter. 2020. "Frequently Requested Statistics on Immigrants and Immigration in the United States." Migration Policy Institute. https://www.migrationpolicy.org/article/frequently-requested-statistics-immigrants-andimmigration-united-states.

Clemens, Michael A., Ethan G. Lewis, and Hannah M. Postel. 2018. "Immigration Restrictions as Active Labor Market Policy: Evidence from the Mexican Bracero Exclusion.” American Economic Review 108(6):1468-87.

Hale, Thomas, Anna Petherick, Toby Phillips, Samuel Webster. "Variation in Government Responses to COVID-19." Version 3.0. Blavatnik School of Government Working Paper.

Hopkins, Emma, Francesca Bastagli, and Jessica Hagen-Zanker. 2016. "Internal migrants and social protection: a review of eligibility and take-up." Working Paper 436, ODI, London.

Kluge, Hans Henri, Zsuzsanna Jakab, Jozef Bartovic, Veronika D’Anna, and Santino Severoni. 2020. "Refugee and Mirant Health in the COVID-19 Response." The Lancet. https://www.thelancet.com/journals/lancet/article/PIIS0140-6736(20)30791-1/fulltext.

ILO. 2020. “COVID-19: Impact on Migrant Workers and Country Response in Malaysia.” ILO, Geneva.

ILO. 2020b. “COVID-19: Impact on Migrant Workers and Country Response in Thailand.” ILO, Geneva.

ILO. 2020c. "Protecting Migrant Workers during the COVID-19 Pandemic: Recommendations for Policy-makes and Constituents." ILO, Geneva.

IOM. 2020. "Migrants and the COVID-19 Pandemic: An Initial Analysis.”

IOM. 2020b. “COVID-19 Response: Situation Report 2.” IOM Myanmar.

IOM. 2020c. “COVID-19 Analytical Snapshot \#16: International Remittances.”

Migration Policy Institute (MPI). 2020. "Immigrant Workers: Vital to the U.S. COVID-19 Response, Disproportionately Vulnerable.” MPI, Washington, D C..

Migration Policy Institute (MPI). 2020b. “A Race Against the Clock: Meeting Seasonal Labor Needs in the Age of COVID-19." Washington, D.C..

Mobarak, Mushfiq. 2020. “Responding to COVID-19 in Developing Countries.”

UNDESA. 2018. The Report on the World Social Situation 2018. New York: UNDESA. 
UNDESA. 2019. The Report on the World Social Situation 2019. New York: UNDESA.

UN (United Nations). 2020. "Shared Responsibility, Global Solidarity: Responding to the SocioEconomic Impacts of COVID-19." UN, Washington, D.C.

World Bank. 2020. East Asia and Pacific in the time of COVID-19. World Bank East Asia and Pacific Economic Update. April 2020.

World Bank. 2020b. "Assessing the Economic Impact of COVID-19 and Policy Responses in SubSaharan Africa." Africa's Pulse 21, World Bank, Washington D.C.

World Bank. 2020c. "Economic and Social Impacts of COVID-19: Update from Listening to the Citizens of Uzbekistan."

World Bank. 2020d. “COVID-19 Crisis Through a Migration Lens.”

World Bank. 2016a. Migration and Development: A Role for the World Bank Group. Washington, DC: World Bank. 
Annex 1: Migration-related responses to COVID-19 around the world ${ }^{2}$

\begin{tabular}{|c|c|c|c|}
\hline Country & Beneficiary & $\begin{array}{c}\text { Sending or } \\
\text { Receiving }\end{array}$ & Intervention \\
\hline Argentina & International & Receiving & $\begin{array}{l}\text { Province of Buenos Aires } \\
\text { - Municipalities will allow health professionals with degrees from abroad that have not been validated in } \\
\text { Argentina to practice medicine; the measure is aimed at Venezuelan health professional in Argentina }{ }^{\mathrm{xxxi}}\end{array}$ \\
\hline Australia & International & Receiving & $\begin{array}{l}\text { - Extending visa duration for workers from the Pacific islands already in Australia under the Seasonal Worker } \\
\text { Program and Pacific Labor Scheme to address farm labor shortages } \\
\text { - Removal of visa barriers to moving from one approved employer to another for seasonal workers } \\
\text { - Actively seeking to move migrant workers under the Pacific Labor Scheme to new employers where existing } \\
\text { employment has ceased as a result of the crisis } \\
\text { - Working holiday maker visa holders employed in agriculture are now exempt from the six month work } \\
\text { limitation with the one employer and eligible for a further visa to keep working in these sectors if their } \\
\text { current visa is due to expire } \\
\text { - Australian Minister for Families and Social Services indicated to extend Special Benefit eligibility, but for only } \\
\text { certain categories of migrant workers (and not Pacific island workers under the Seasonal Worker Program } \\
\text { or Pacific Labor Scheme) } \\
\text { - Temporary migrant workers are able to withdraw up to } \$ 10,000 \text { in superannuation each year (for two } \\
\text { - Tears) where unemployed } \\
\text { per fortnight in the supermarket and aged care sector.xxxii } \\
\text { State of Tasmania } \\
\text { - The Government of Tasmania announced a } \$ 3 \text { million package to support temporary visa holders such as } \\
\text { fruit pickers, students and hospitality workers. Visa holders who can demonstrate immediate financial } \\
\text { hardship will be eligible for AUD250 for individuals, and AUD1,000 for families.xxxii }\end{array}$ \\
\hline Austria & International & Receiving & $\begin{array}{l}\text { - On March 30, } 231 \text { care workers were flown to Austria to provide round-the-clock care in the region of Lower } \\
\text { Austria, which organized flights from the Bulgarian capital Sofia and the Romanian city of Timisoara. xxxiv } \\
\text { - Reduction of foreign workers' hours/salary under the special government program called 'Kurzarbeit' should } \\
\text { not in practice negatively affect work/residence authorization if it meets certain criteria (often on a case by } \\
\text { case basis). Minimum salary requirements can be pro-rated if employees must be placed on unemployment } \\
\text { partially or fully. The agreed salary must be kept on a pro rata basis. } x x x v\end{array}$ \\
\hline Bahrainxxxvi & International & Receiving & $\begin{array}{l}\text { - Bahrain's Labour Market Regulatory Authority (LMRA) announced an amnesty for irregular migrants until } \\
\text { December 31,2020. Regularization of residency status will not be subject to fines or to the requirement to } \\
\text { leave the country. } \\
\text { - Starting on April 1,2020, LMRA also cancelled monthly work permit fees and fees related to issuing and } \\
\text { renewing work permits for three months }\end{array}$ \\
\hline
\end{tabular}

2 The interventions listed in this table do not cover the whole set of migration-related interventions applied in different countries in response to the COVID-19 outbreak. 


\begin{tabular}{|c|c|c|c|}
\hline & & & $\begin{array}{l}\text { - The LMRA also announced that it has cut fees for the Flexi-Permit by } 60-78 \% \text {. The Flexi Permit now costs BD } \\
167 \text { (443 USD) for one year and the cost of renewal will be BD } 72 \text { (191 USD). It was earlier BD } 427 \text { annual } \\
\text { fees and BD } 322 \text { for renewal. } \\
\text { - Flexi-Permit holders will not be charged any monthly fees until the end of June. The LMRA's Flexi } \\
\text { Permit website has been updated accordingly. This move will be especially beneficial for those who already } \\
\text { have the Flexi-Permit but cannot afford renewal fees amidst the current economic downturn and loss of jobs, } \\
\text { and for those who wish to regularise their status but cannot find full-time employment. } \\
\text { - Applications for the Flexi-Permit will be done remotely but migrants must be present in person to collect the } \\
\text { Flexi-Permit and provide biometric details. Irregular workers will not need their passports to apply. } \\
\text { - A Ministry of Labour and Social Development's administrative circular sets out the responsibilities of } \\
\text { employers (and workers) in the private sector (including employers with workers in labor camps) to ensure } \\
\text { that: } \\
\text { - labor accommodations house a reduced number of workers in a room; } \\
\text { - } \quad \text { workers must be at least three meters away from each other in a room; } \\
\text { - toilet and sanitation facilities in the labor camp are increased; } \\
\text { - Employers provide an isolation facility to treat any worker if tested positive for COVID-19. }\end{array}$ \\
\hline Belgium & International & Receiving & $\begin{array}{l}\text { - Asylum seekers are given access to the labor market provided that they have properly submitted their } \\
\text { application to the office of the commissioner general for refugees and stateless persons. They will have the } \\
\text { opportunity to work during the duration of the procedure, including during the duration of any appeal to the } \\
\text { Aliens Litigation Council. xxxiii } \\
\text { - Measures have been taken to facilitate the administrative procedures and all care provided to undocumented } \\
\text { migrantsxxix } \\
\text { - Foreign workers on reduced hours/salary can maintain their work/residence status for the duration of the } \\
\text { pandemic. Regional employment authorities will not require compliance with the immigration salary } \\
\text { threshold during the period of suspension of the employment contract, irrespective of whether employees } \\
\text { are entitled to Belgian unemployment benefits. }{ }^{x l}\end{array}$ \\
\hline \multirow[b]{2}{*}{ Brazil } & Internal & - & $\begin{array}{l}\text { - Considering extending coverage in response to the crisis, topping up CCT Bolsa Familia and the social } \\
\text { pension scheme }\end{array}$ \\
\hline & International & Receiving & $\begin{array}{l}\text { - A bilateral agreement was signed between Brazil and Chile to facilitate return zones and allow citizens of } \\
\text { both countries as well as permanent residents to cross the border freely. xli } \\
\text { - In April, the Federal Government introduced a monthly emergency basic income of } 600 \text { BRL (USD 120) for } \\
\text { persons who lost their livelihoods because of the pandemic, regardless of their nationality, for up to } 3 \\
\text { months. xlii } \\
\text { - Refugees and migrants from Venezuela continue to have access to public healthcare services. xliii }\end{array}$ \\
\hline Bulgaria & International & Receiving & $\begin{array}{l}\text { - Automatic extension of residence permits (of } 6 \text { months duration or longer) for EEA members and third- } \\
\text { country nationals with long-term or permanent residence if permit expires between January } 1,2020 \text { and } \\
\text { October } 31,2020 \text {.xliv }\end{array}$ \\
\hline Canada & International & Receiving & $\begin{array}{l}\text { The Minister of Public Safety announced that foreign students, foreigners with a work visa and temporary } \\
\text { foreign workers will be able to enter Canada, despite the closing of the borders to the extent that they will } \\
\text { have to undergo a period of isolation from } 14 \text { days. xlv }\end{array}$ \\
\hline
\end{tabular}




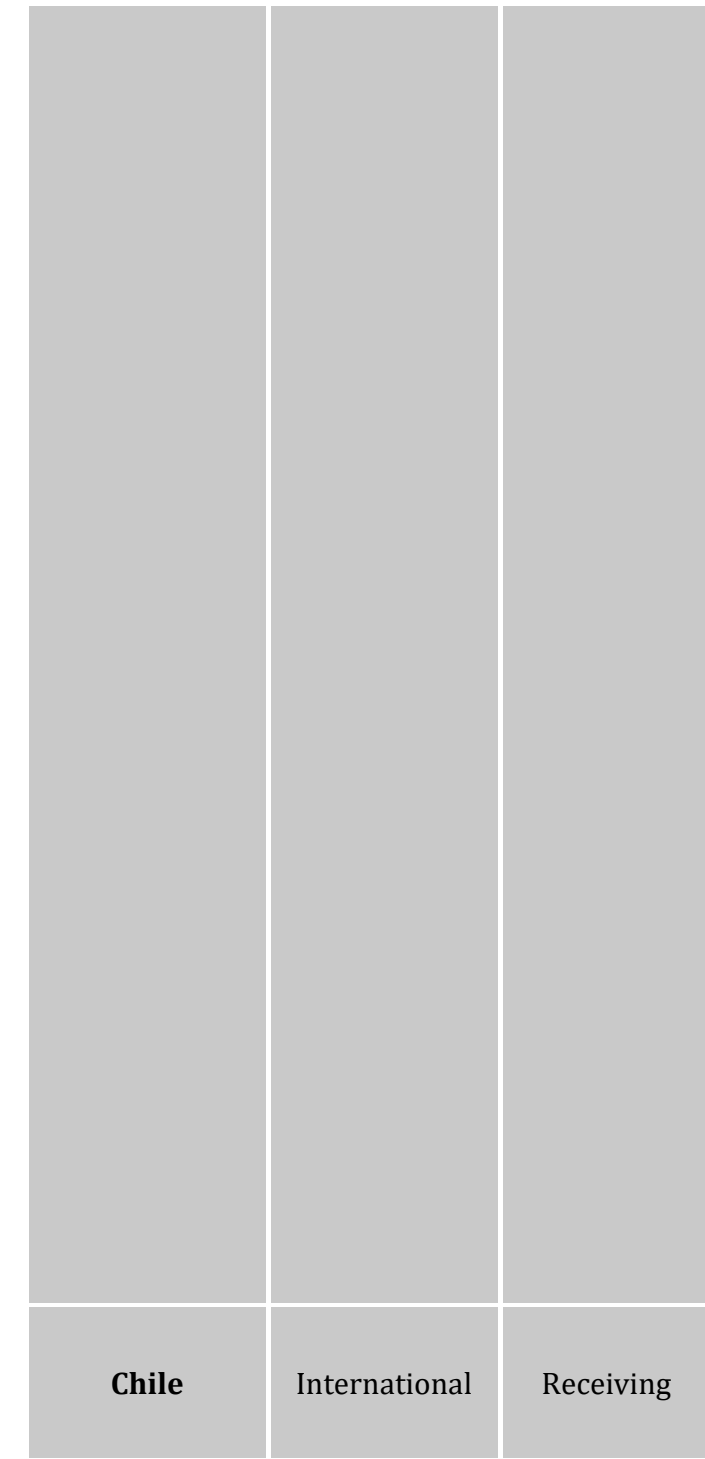

- The Canadian Federal Government announced that under the new International Mobility Program it is now mandatory for employers to allow workers to complete their 14 days of quarantine on arrival in Canada and pay them for the period, even if they are unable to workxlvi.

- The Federal Immigration Minister announced that applications are now being accepted for Canada's new AgriFood Immigration Pilot (AFIP). The AFIP is a three-year pilot targeting labor shortages in the meat processing, year-round mushroom and greenhouse crop production and livestock raising industries. Under the AFIP, 2,750 applications will be accepted annually, primarily providing a pathway to permanent residence for many temporary foreign workers already in Canadaxlvii.

- Under a new public policy, published on May 12, foreign workers already in Canada with a new job offer backed by a Labour Market Impact Assessment (LMIA) can get approval to start the job while their work permit application is processed. The new policy aims to free TFWs who have lost their jobs in Canada due to COVID-19 to work in industries where there are shortages. This move is expected to reduce a process that often takes 10 weeks down to 10 days.xlviii

- Several provinces in Canada are using province-specific immigration programs to expedite the inflow of workers into industries in need of labor due to Covid-19. For example, in Prince Edwards Island immigration invitations have been issued to specific COVID-19 essential workers in the healthcare and trucking industries ${ }^{x l i x}$. Nova Scotia conducted a new draw aimed at nurses!.

\section{Province of British Columbiali}

- Temporary foreign workers with a permit of less than 6 months, who would otherwise not be eligible for coverage under the Medical Service Plan (MSP), will be provided temporary MSP coverage to July 31, 2020 or the end of the permit, whichever is sooner.

\section{Province of Ontariolii}

- The province will cover the cost of COVID-19 services for uninsured people who do not meet the criteria for Ontario Health Insurance Plan coverage

\section{Province of Quebecliii}

- Any person living in Quebec can do a COVID-19 test free of charge and receive treatment free of charge if they test positive for COVID-19. This applies regardless of immigration status.

- Several compensation programs have been put in place to assist workers who have lost their jobs due to COVID-19. These programs are not restricted to Canadian citizens or permanent residents. Workers can be eligible for these programs if they have a valid work permit and are a foreign worker, an international student, a refugee claimant or an accepted refugee.

- Chile has set up an online system through which visas and stay permits are extended for six months, upon request. liv

- A bilateral agreement was signed between Brazil and Chile to facilitate return zones and allow citizens of both countries as well as permanent residents to cross the border freely. Iv 


\begin{tabular}{|c|c|c|c|}
\hline China & Internal & - & $\begin{array}{l}\text { - Cash transfer } \\
\text { O Cash transfer for retention migrant population in Wuhan. One-time cash assistance of RMB } 3000 . \\
\text { Onemployment assistance. Using the unemployment insurance fund to provide cash support for those } \\
\text { who are temporarily unemployed, but do not meet the conditions to claim for unemployment insurance } \\
\text { benefits. } \\
\text { - Unemployment insurance benefits. The unemployed workers can claim for the unemployment insurance } \\
\text { benefits. } \\
\text { - Households with unemployed members could apply for Dibao and temporary social assistance. } \\
\text { - Demand side intervention } \\
\circ \text { Exempt, reduction and postponement of social insurance contributions, housing funds, and utility costs. } \\
\text { Wage and job subsidies by using unemployment insurance funds to stabilize employment. } \\
\text { Tax exempt, financial and credit support to increase liquidity of enterprise. } \\
\text { Encourage localities to create more job opportunities by investing locally. } \\
\text { Employment services } \\
\text { "Point to Point" chartered transportation services (buses, training, flights) to send migrant workers } \\
\text { from hometowns to enterprises. Local governments cover the total or partial transportation costs. } \\
\text { Public works. Government will create public welfare job posts (such as sanitation and epidemic } \\
\text { prevention) for migrant workers who are temporarily unable to go out and have difficulty in living. } \\
\text { Online job fairs, interview and recruitments. MOHRSS provided an online platform to serve for this } \\
\text { purpose. } \\
\text { Online skilling development program financed by the unemployment insurance funds. }\end{array}$ \\
\hline Costa Rica & International & Receiving & $\begin{array}{l}\text { - Costa Rica and Panama have signed a bilateral agreement to coordinate migrant flows through their common } \\
\text { border, including provisions for medical examinationslvi }\end{array}$ \\
\hline Croatialvii & International & Receiving & $\begin{array}{l}\text { - Foreign nationals can apply online for a one-year extension of Temporary Stay for work/stay/family } \\
\text { reunification up to } 60 \text { days before expiration of their permit. } \\
\text { - Foreign nationals can continue working with an expired Residence Permit and will not be penalized for } \\
\text { missing the extension application deadline. }\end{array}$ \\
\hline Denmark & International & Receiving & $\begin{array}{l}\text { - Foreign nationals with approved permits can start work from their home country, provided that their } \\
\text { employment contract or assignment letter is in effect, despite not having collected a visa (normally required } \\
\text { for visa nationals) or receiving salary at a Danish bank account (normally required for Pay Limit Scheme } \\
\text { permit holders). viiii }\end{array}$ \\
\hline Ecuador & International & Receiving & $\begin{array}{l}\text { - Introduced an extension in the deadline for Venezuelan migrants on its territory to apply for a humanitarian } \\
\text { visa until the end of the state of emergency. }\end{array}$ \\
\hline Finland & International & Receiving & $\begin{array}{l}\text { The Finnish government decided to increase the number of agricultural workers admitted to the country } \\
\text { from outside the European Union (EU) and announced plans to allow asylum seekers to take up agricultural } \\
\text { work without administrative delays. EU citizens have been allowed to travel in the country for work since } \\
\text { May 14.1x }\end{array}$ \\
\hline France & International & Receiving & $\begin{array}{l}\text { The unemployment agency in France has created a website designed to match farmers with workers, and } \\
\text { will allow workers who fill agricultural jobs to continue receiving benefits and income if they have been } \\
\text { furloughed }\end{array}$ \\
\hline
\end{tabular}




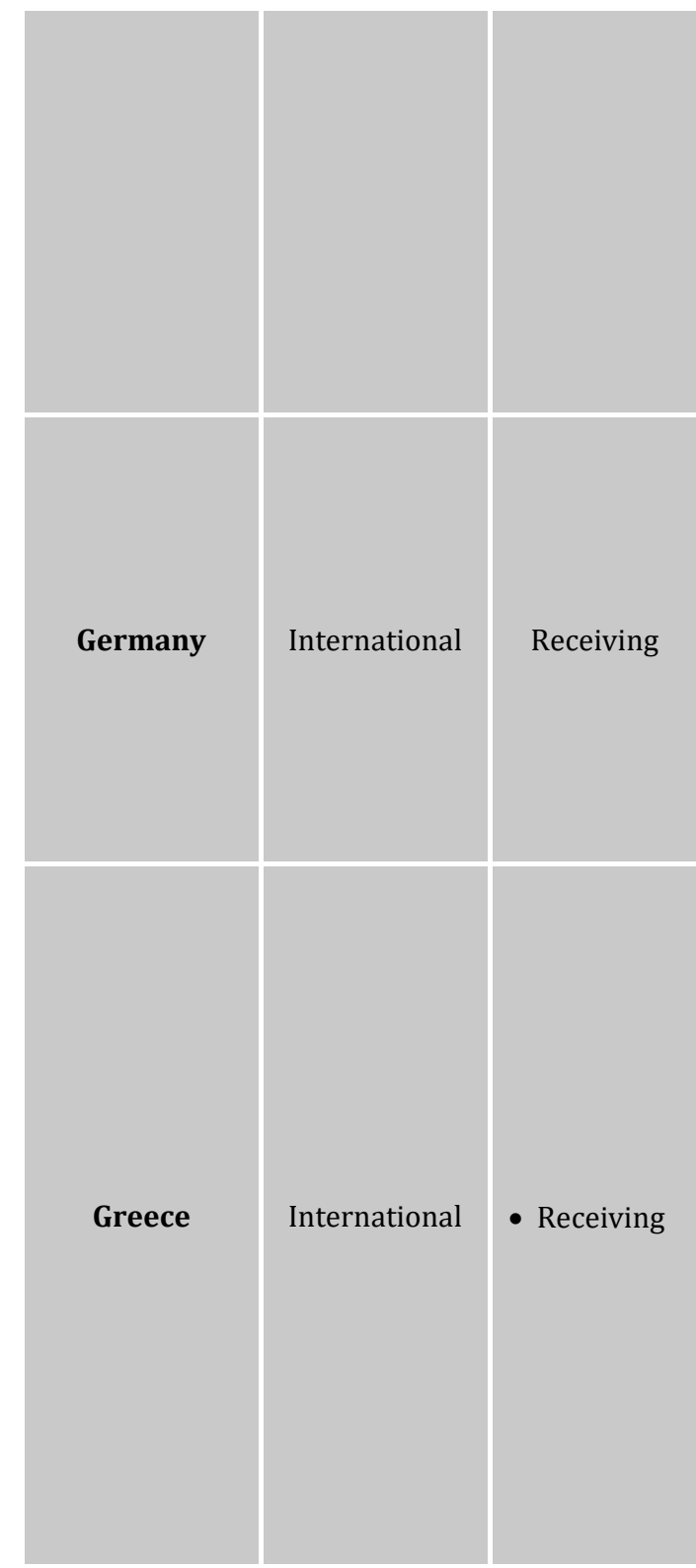

- Residence permits for lawfully residing foreign nationals expiring March 16-May 15, 2020 are automatically extended for six months. Short stay visa holders do not benefit from the automatic extension. However, if faced with difficulties leaving France due to COVID-19 related restrictions, they can request an extension from the prefecture. Several prefectures have started receiving online applications for extension of the short stay visa. ${ }^{\mathrm{x} i}$

- The Partial Activity Scheme allows employers to reduce employees' work hours and pay up to $100 \%$ of their salary, for a maximum of 12 months. Under this scheme, the government covers an hourly compensation capped at $70 \%$ of the remuneration, with a maximum of 35 work hours and up to 4.5 times the minimum wage. Employers may elect to pay their employees the remaining amount not covered by the government. Employers who choose to use this Scheme do not risk losing a work permit if they reduce an employee's salarylxii

- Most support provided to respond to the COVID-19 outbreak is provided irrespective of migration status though ordinary restrictions still apply (e.g. expanded compensation for short-term work applies irrespective of the migration status of the workerlxiii, as does the immediate assistance and stabilization fund set up to support businesses ${ }^{\text {lxiv }}$ )

- Created a website to match German volunteers with farmers, leading 42,000 to sign up,

- Announced a reversal of its ban on seasonal agricultural migrant workers entering the country. Farmers will be able to bring in 80,000 workers in April and May. The seasonal workers will arrive by plane, receive a health check, and be required to be separated from local workers for two weeks. ${ }^{\mathrm{lxv}}$

- Simplification of asylum seekers' access to jobs in agriculturelxvi

- Some states have reduced conditionalities for accessing basic income support for refugees ${ }^{l x v i i}$

- Some states have allowed foreign doctors whose accreditation is still pending to be immediately deployed under the supervision of licensed physicians ${ }^{\text {Ixviii }}$

- Greece has suspended asylum services, but has said that asylum applications and residency permits will remain valid during the suspension

- Residence permits or blue receipts that expired from February 11-May 12, 2020 are automatically renewed for up to five months after their expiration date.lxix

- The work/residence authorization for furloughed foreign workers or those placed on unemployment or whose hours or salary are reduced is not affected. Renewal applications for EU Blue Card holders whose salary was reduced may be negatively affected, but will be reviewed on case by case basis. .xx $^{\mathrm{k}}$

- A Temporary Aliens Provisional Insurance and Health Care Number (PAAYPA) will be issued to all asylumseekers who are fully registered and holders of valid asylum-seeker cards. The PAAYPA number will be issued automatically together with the asylum-seeker card by the Asylum Service and will ensure the provision of healthcare. In case the asylum claim is rejected, the PAAYPA will be automatically deactivated. In case the asylum claim receives a positive decision, it will become an social security (AMKA)number.

- All supporting measures provided to employees and unemployed people to respond to the COVID-19 crisis are implemented irrespective of migration status if beneficiaries are formally working in the Greece or are registered with The Greek Employment Agency (OAED).

- Benefits such as the Social Solidarity Income will continue to be provided to the current beneficiaries. In addition, beneficiaries will be informed via SMS and emails that their applications are valid for one more month without having to visit the municipality or the community center for re-certification/re-application. This applies to both citizens and non-citizens. 


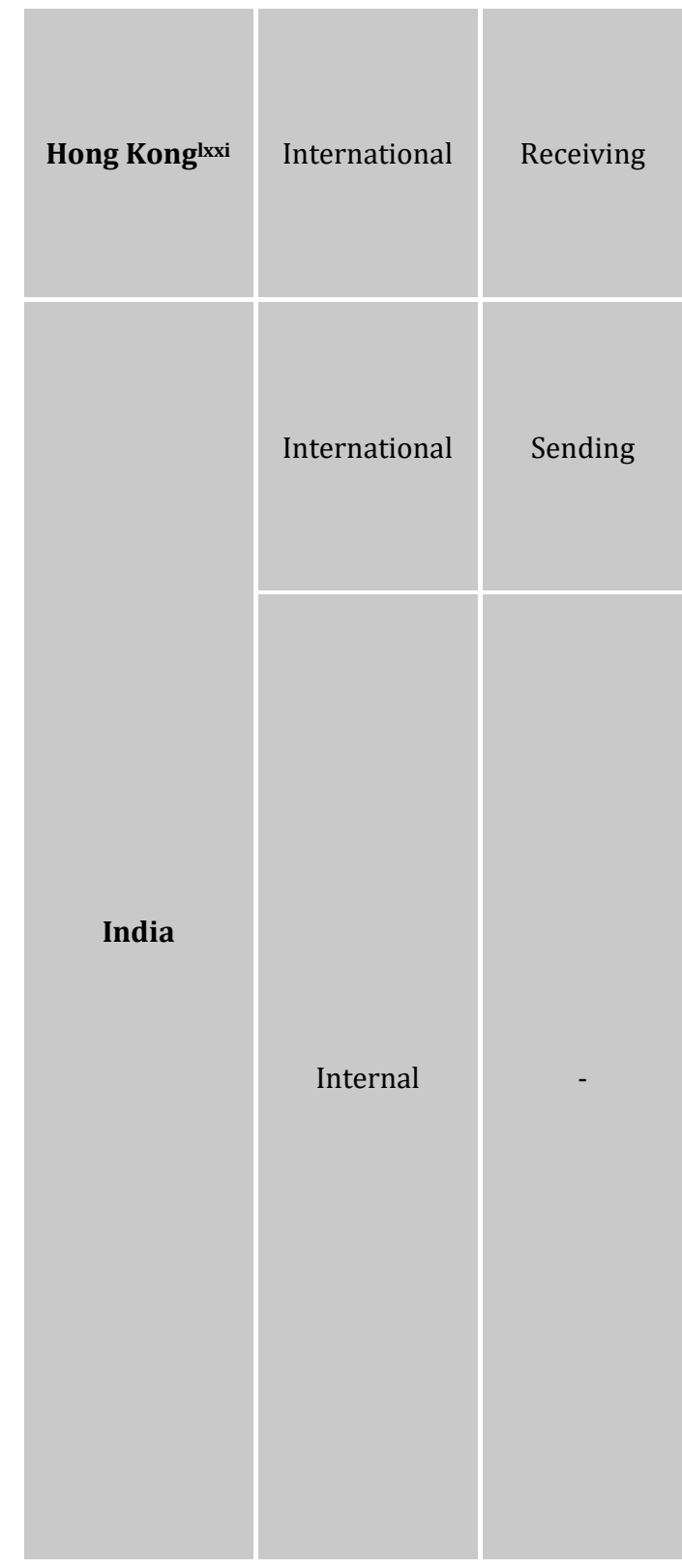

- A one-off transfer of HK\$10,000 (US\$1,280) is planned for permanent residents over the age of 18 . This measure, which involves a cost of about HK $\$ 71$ billion is expected to benefit about 7 million people. A community care fund has been designated to extend this assistance to more recent immigrants who are low income and have yet not achieved permanent residency status. lxxii

- The Commissioner for Labour has given in-principle consent for all Foreign Domestic Helper that expire on or before March 31, 2020, to be extended up to May 31, 2020.

- The measure now also covers contracts that expire on June 30,2020 , and that can be extended to July 31 , 2020.

- The Government is working with some Arab Gulf states in an effort to repatriate hundreds of thousands of migrant laborers stranded by the coronavirus pandemic, in what could become one of the largest emergency evacuations in decades. Starting in a few days, India plans to begin deploying military ships and its national airline for the effort, while Kuwait and the United Arab Emirates use civilian airliners. The first wave of repatriations could bring 192,000 Indians home by mid-Junelxxiii

- The repatriation of workers from Saudi Arabia started on May 8 when 152 workers were flown from Riyadh to Kozhikode in Kerala. This was the first of several flights that are expected to repatriate approximately 1,000 workers in the first phase. ${ }^{\text {xxiv }}$

- The Indian government will assist stranded migrants travelling by special trains to their home states. The central government will pay 85 percent of the ticket prices and the remaining 15 percent will be borne by the state governments. ${ }^{\text {Ixx }}$

- On May 14, The World Bank's Board of Executive Directors today approved a \$1 billion Accelerating India's COVID-19 Social Protection Response Program to support India's efforts at providing social assistance to the poor and vulnerable households, severely impacted by the COVID-19 pandemic. This project will enable state governments to provide support to migrants without regard to their state of residence and make access to certain benefits portable across state boundaries. ${ }^{x x v i}$

- The Ministry of Home Affairs has requested all state governments to flexibly use resources in the State Disaster Response Funds tolxxvii:

- provide a package of shelter, food and free testing to vulnerable people, including interna migrants, stranded due to lockdown measures in their respective areas.

- introduce employment retention policies to ensure that workers, including migrants, receive their wages without deductions during the lockdown

- ensure that rent payment for workers, including migrants, is suspended for one month and that workers and students are not forced to vacate their accommodation during the lockdown period

While these measures have recently been announced, enforcement will be key to ensure that migrants receive adequate support

- The government is also planning to top up pre-existing social assistance programs (such as PM-KSN MGNREGS and UJWALA) as part of its COVID-19 social protection response. However, these programs are implemented at the state level and automatically exclude migrants as applicants must prove that they are residents of a particular state as part of the eligibility determination process. While the government could consider a direct cash transfer to all migrants by linking the near-universal ration card and Aadhaar to 


\begin{tabular}{|c|c|c|c|}
\hline & & & $\begin{array}{l}\text { trigger payments, any such transfer will require the government to relax rules which target benefits to state } \\
\text { residents. } \\
\text { - State governments are relying on Kudumbashree groups and self-help groups (in Tripura and South Goa) to } \\
\text { run community kitchens for migrant workers, homeless persons, and destitute households. }\end{array}$ \\
\hline Indonesia & International & Sending & $\begin{array}{l}\text { - Indonesia migrant workers protection agency (BP2MI) has facilitated returned of Indonesian migrants from } \\
\text { Malaysia (undocumented as well as documented owing to lockdowns in Malaysia) }\end{array}$ \\
\hline Irelandlxxviii & International & Receiving & 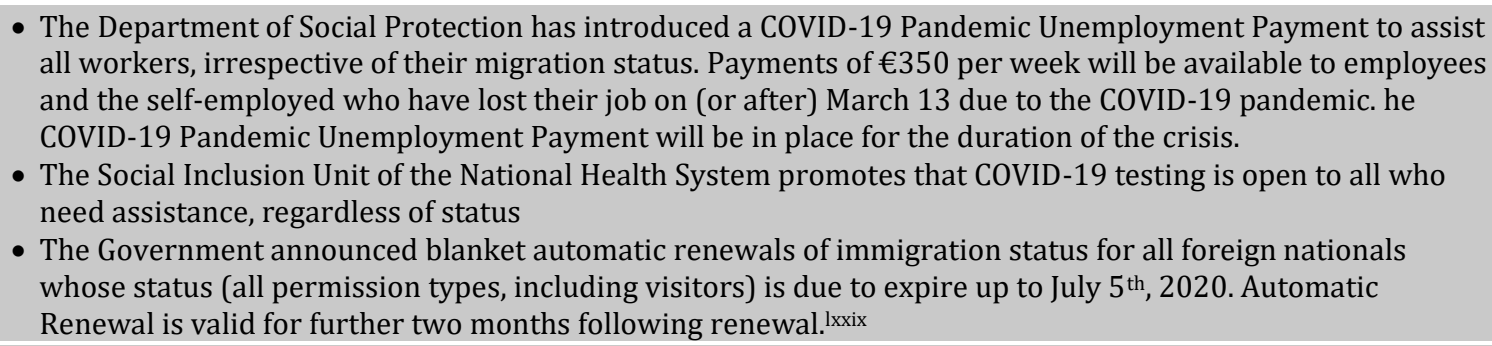 \\
\hline Italylxxxlxxxi & International & Receiving & 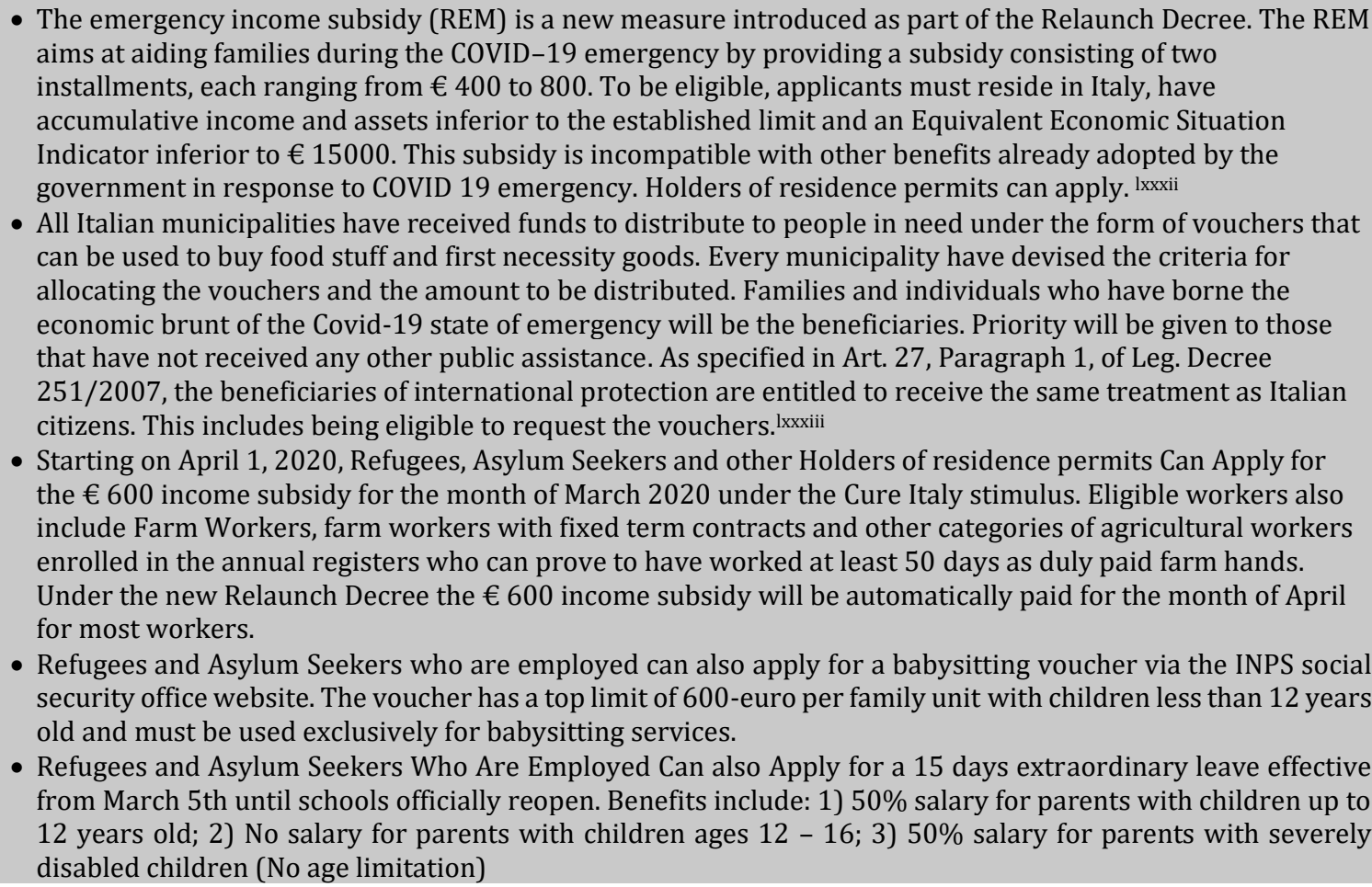 \\
\hline
\end{tabular}




\begin{tabular}{|c|c|c|c|}
\hline & & & $\begin{array}{l}\text { - The Government announced a six-month amnesty for thousands of undocumented migrants. foreign laborers } \\
\text { in the agricultural and domestic working sectors who have been without a valid residency permit since } \\
\text { November will be able to apply. The new residency permits will be valid for six months. Employers who have } \\
\text { irregularly hired either foreign or Italian workers in these sectors would also able to apply to regulate their } \\
\text { staff by stipulating a fixed-term employment contract.lxxxiv } \\
\text { - All residence permits expiring between January } 31,2020 \text { and April } 15,2020 \text { are now valid until June } 15,2020 \text {. } \\
\text { - All recognition and identity documents, issued by the competent Italian authorities, which have expired or } \\
\text { expired in the days following } 18 \text { March } 2020 \text { are extended to } 31 \text { August } 2020 \text {. } \\
\text { The Regional Government of Campanialxxxv } \\
\text { - As part of a larger support package, special funding was allocated to African communities who work in } \\
\text { agriculture and who would otherwise remain unprotected. The funding will support the arrangement of } \\
\text { buildings for temporary housing for immigrants, the purchase of transport services to support safe mobility } \\
\text { and counter the risk of contagion among workers, mediation services and psychological support, } \\
\text { communication and information campaigns to increase awareness of the risks of the epidemic and contain } \\
\text { contagion, and interventions to guarantee medical and nursing services and the purchase of hygiene kits. }\end{array}$ \\
\hline Japan & International & Receiving & $\begin{array}{l}\text { - On April 16, Prime Minister Shinzo Abe announced a } ¥ 100,000(\$ 930) \text { handout scheme for all citizens and } \\
\text { foreign residents, with payouts expected as early as May. Everyone who has resided in Japan for at least } \\
\text { three months and is registered as a basic resident as of April } 27,2020 \text {, is eligible for this assistance. xxxvi } \\
\text { - Foreigners whose visa will expire between March and June will benefit from a three-month visa extension } \\
\text { - Work-permit holders who are currently abroad and cannot enter Japan due to travel restrictions will be } \\
\text { allowed to return even if the re-entry permit has been expired. }\end{array}$ \\
\hline Jordan & International & Receiving & $\begin{array}{l}\text { - The Jordanian government has agreed to waive all labor-related fines and fees for expat workers wanting to } \\
\text { return to their home countries. The country's labor minister has called on migrant workers to apply through } \\
\text { an online platform that coordinates their repatriation amid the coronavirus outbreak. The application } \\
\text { deadline is May } 4 \text {. The Minister added that fines and fees related to work permits will be waived, even for } \\
\text { illegal migrant workers in the country. Ixxxvii }\end{array}$ \\
\hline Kazakhstan & International & Receiving & - Temporary migrants have access to free medical clinics for COVID-19 \\
\hline Kenya & International & Receiving & $\begin{array}{l}\text { - In line with Migrant Workers (Supplementary Provisions) Convention, } 1975 \text { (No. 143), draft Guidelines on } \\
\text { COVID-19 Pandemic at the Workplace, Kenya Ministry of Labour and Social Protection indicated that regular } \\
\text { migrant workers who lose their job as a result of COVID-19, shall not be regarded as irregular migrants. Their } \\
\text { residence or work permit shall remain valid for the time period stipulated previously. } \text { lxxviii }\end{array}$ \\
\hline Korea & International & Receiving & $\begin{array}{l}\text { - Introduced flexibility in the Employment Permit System to minimize impacts on firms and EPS workers by: } \\
\text { Extending the employment contract by } 50 \text { days for those whose employment terms are approaching; } \\
\text { Supporting recruitment of new EPS workers, who cannot leave their home countries, from other } \\
\text { countries of origin; } \\
\text { Operating EPS-related business through one-stop service } \\
\text { - Extending the job search period for EPS job changers. } \\
\text { leave subsidies } \\
\text { - In response to no new inflows of seasonal agriculture workers from abroad, the government has taken } \\
\text { measures to utilize foreigners who are currently in the country, including: }\end{array}$ \\
\hline
\end{tabular}




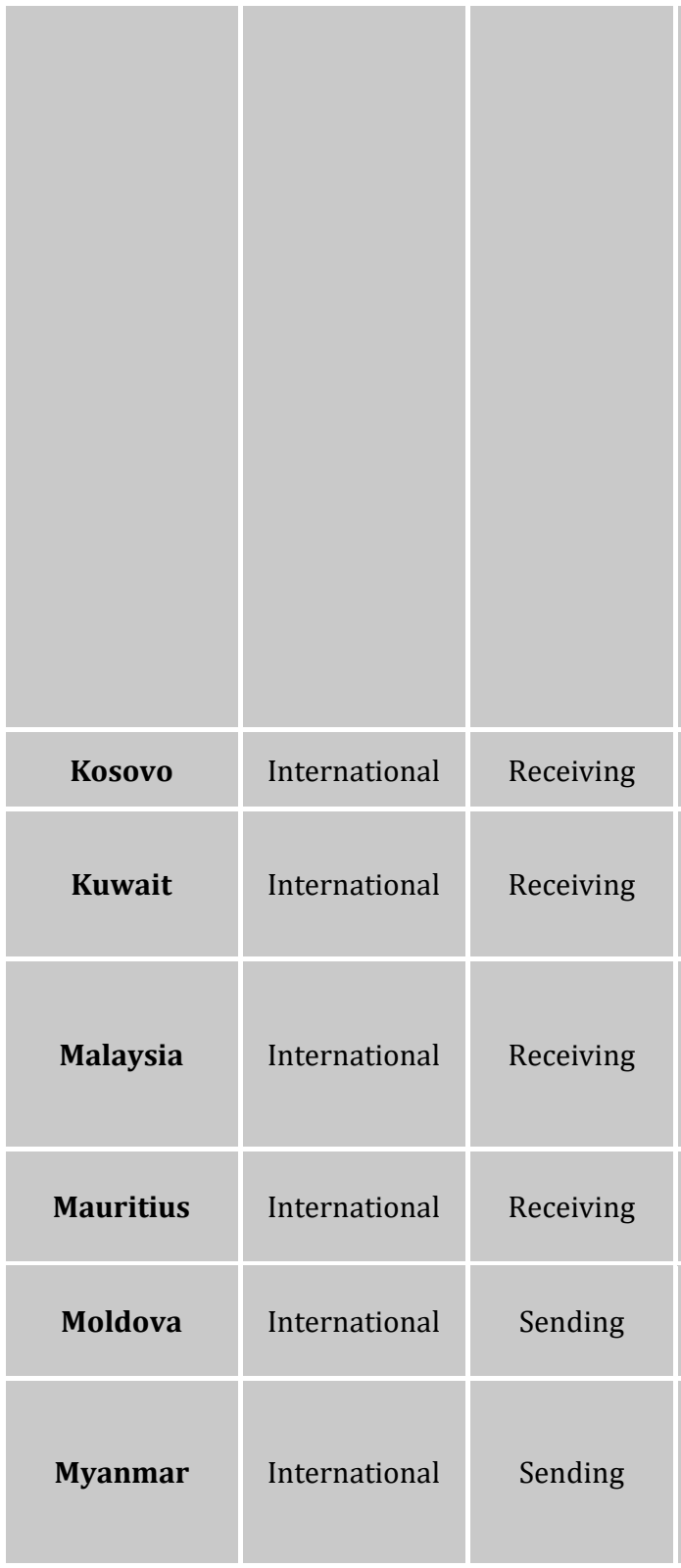

- setting up additional agriculture job-matching centers close to farmers,

- relaxing sector regulations to match job-seeking EPS workers (even if whose permit is for the manufacturing sector, for instance) with seasonal agriculture jobs

- Permitting people in Korea under a family visa, to seek seasonal agriculture jobs.

- These measures are in parallel with local governments/communities' actions to boost volunteering by natives.

- Irregular foreign workers

- All irregular foreign workers have access to free COVID-19 testing and treatment. During their treatment, the government provides partial income support. During the crisis, hospitals are not mandated to ask their status and to report their admissions (personal details) to the Immigration/ labor authorities.

- Irregulars who leave Korea voluntarily by June will be exempt from penalties and from the no-futureentry rule.

- Employers who voluntarily report the employment of irregulars by end March will be exempt from financial penalties as well as from the EPS penalty - ineligibility to hire EPS workers in the future.

Furthermore, taking into account difficulties with new hires, the employers can keep the employment of irregulars for 3 additional months, before sending them back to their home countries.

- The Thai Ministry of Labor is coordinating with the Korean labor offices to make sure that Thai laborers receive pending wages and benefits.

- Residence permits valid on or after March 16, 2020 are automatically extended for the duration of the pandemic.lxxxix

- The Government introduced a special amnesty for More than 4,300 undocumented Bangladeshi migrant workers. Their expenses -- airfare, food and accommodation -- during repatriation will be borne by Kuwait government. Undocumented workers will be able to return home without any fine and will be eligible to reenter the Gulf country through legal channels in the future.xc

- Extension of eligibility to undocumented migrants for COVID-19 tests and treatment

- Foreign worker levy cut by $25 \%$ for those with permit ending Dec 31, 2020, but discount not applicable for domestic helpers $\mathrm{xci}$

- Foreign workers are allowed to apply online to renew their Temporary Employment Visit Passes (PLKS) which expire during the movement control order (MCO)xcii

- All residence permits set to expire during the curfew period have been extended for three months. Those needing to extend their residence permits will be given an appointment to renew their permits once the curfew has lifted.xciii

- Minimum unemployment benefit is set to 2775 lei/month (US\$157), mostly to the benefit of returned migrant workers and other potentially ineligible categories who are made eligible for the emergency period under condition of purchasing the medical insurance (4056 lei or US\$229.5 for a year) ${ }^{x c i v}$

- On 25 April, the Office of the Labour Attaché at the Myanmar Embassy in Bangkok, announced it would organize relief flights for Myanmar migrants stranded in Thailand (Myanmar embassies around the world also announced relief flights) $\mathrm{xcv}$

- The border with Thailand was expected to re-open on 1 May to allow a second large influx of migrants (estimated 20,000 to 50,000 returns). The Myanmar Government requested to the Thai Government to only 


\begin{tabular}{|c|c|c|c|}
\hline & & & $\begin{array}{l}\text { allow 2,500 returnees per day through the Myawaddy border gate; however, due to the extension of the } \\
\text { Emergency Decree in Thailand until } 31 \text { May, returns are delayed for a few more days to allow for the necessary } \\
\text { arrangements to be put in place by Thai authorities. xcvi }\end{array}$ \\
\hline & Internal & - & $\begin{array}{l}\text { The Livelihood and Food Security Fund (LIFT) announced new funding to support about } 5.9 \text { million people, } \\
\text { including: migrants, the elderly, internally displaced people, pregnant women and those with children aged } \\
\text { under two. Specifically, } \$ 2.9 \text { million are allocated for immediate assistance to migrants to prevent the spread } \\
\text { of the virus and to provide economic and legal support. The allocation includes } \$ 1.7 \text { million to support an } \\
\text { estimated 310,000 internal migrants in peri-urban areas, and } \$ 1.2 \text { million for } 110,000 \text { returned migrant } \\
\text { workers. xcvii }\end{array}$ \\
\hline Nepal & International & Sending & $\begin{array}{l}\text { - The Minister of Foreign Affairs announced that the government is working on a series of measures that } \\
\text { involve safe repatriation of workers, their quarantine and employment in the labor market. When the } \\
\text { repatriation begins, pregnant women, people who have lost their jobs, those with health issues, those that } \\
\text { have lost a family member back home, and those that have overstayed their visas will be given priority.xviii }\end{array}$ \\
\hline $\begin{array}{c}\text { New } \\
\text { Zealand }\end{array}$ & International & Receiving & $\begin{array}{l}\text { - The government has automatically extended to } 25 \text { September all work, student, visitor, limited or interim } \\
\text { visas due to expire between } 2 \text { April and } 9 \text { July } 2020 \text {. } \\
\text { - Migrants under the Recognized Seasonal Employer program are eligible for sick leave scheme that is part of } \\
\text { NZ's COVID-19 economic response package } \\
\text { - As part of the COVID-19 Economic Response Package, RSE workers are also entitled to government funding, } \\
\text { equating to NZ\$585.50 per worker per week, if they cannot work during the lockdown because their } \\
\text { employer's business is not operating or the employer cannot afford to pay them due to reduced business } \\
\text { activity } \\
\text { - If an RSE worker is required to self-isolate while in New Zealand, due to illness or close contact with a } \\
\text { confirmed COVID-19 case, they are also eligible for the government's wage subsidy. RSE employers apply for } \\
\text { the subsidy on behalf of their workers, and provide accommodation and pastoral care facilities during the } \\
\text { 14-day isolation period. Workers will continue to pay their accommodation and other living costs. } \\
\text { - Under existing medical insurance, RSE workers are entitled to receive medical treatment for any presenting } \\
\text { conditions, including COVID-19, and treatment for the virus will be covered by New Zealand's Ministry of } \\
\text { Health. }\end{array}$ \\
\hline Norway & International & Receiving & $\begin{array}{l}\text { - Residence permits are not revoked if the foreign worker is temporarily laid off, they can continue to stay in } \\
\text { Norway for as long as the permit is valid. Foreign nationals who are laid off can remain in Norway up to six } \\
\text { months to look for another job if their residence permit is valid through this period.c } \\
\text { - A reduction in work hours does not affect foreign nationals' immigration status (or renewal of their } \\
\text { immigration status) as long as they continue to work in at least } 80 \% \text { capacity. Salary reductions do not affect } \\
\text { foreign nationals' immigration status (or renewal of their immigration status) as long as the salary remains } \\
\text { at least at the minimum salary amount.ci }\end{array}$ \\
\hline Panama & International & Receiving & $\begin{array}{l}\text { - The Government of Panamá will offer shelter to around 2,500 migrants at three immigration stations at } \\
\text { Panama's borders with Colombia and Costa Ricacii. } \\
\text { - The government has also provided masks and PPE in shelters in Darien and Gualaca. }{ }^{\text {ciii }} \\
\text { - The Government of Panama agreed to include 20,000 asylum seekers and refugees as potential beneficiaries } \\
\text { in the Panama Solidario Plan aimed at mitigating the economic impact of COVID-19, subject to vulnerability } \\
\text { criteria. }{ }^{\text {civ }}\end{array}$ \\
\hline
\end{tabular}




\begin{tabular}{|c|c|c|c|}
\hline Perucv & International & Receiving & $\begin{array}{l}\text { - The government announced that for the duration of the emergency all foreigners pending regularization are } \\
\text { considered as regulars. } \\
\text { - The government decreed the inclusion of foreign health professionals to strengthen the national healthcare } \\
\text { capacity during the emergency. } \\
\text { - The government decreed the temporal affiliation of refugees and migrants to the health insurance system } \\
\text { (SIS for its acronym in Spanish) specifically for those suspected or confirmed as COVID-19 positive. }\end{array}$ \\
\hline Philippines & International & Sending & $\begin{array}{l}\text { - The Department of Labor and Employment (DOLE)in the Philippines recently announced that cash } \\
\text { assistance amounting to } \$ 200 \text { (over PHP10,000) will be provided to overseas Filipino workers (OFWs) } \\
\text { whose work were affected by the coronavirus disease } 2019 \text { (Covid-19) pandemic. The Government targets to } \\
\text { reach 70,000 OFWs. To avail of the program, OFWs must submit their certificate of employment issued by } \\
\text { their agencies. Their application will be evaluated and processed by the Philippine Overseas Labor Office } \\
\text { (POLO) or Overseas Workers Welfare Administration (OWWA). } \\
\text { - Various Government agencies have expressed their collective decision to add another Philippine P } 5 \text { billion } \\
\text { pesos to support migrant workers from the Gulf and other destinations globallycvi }\end{array}$ \\
\hline Poland & International & Receiving & $\begin{array}{l}\text { - The Polish government extended legality of stay of foreigners residing in Poland on the basis of short-term } \\
\text { residence titles, including visa-free travel. Extension is valid until the end of the } 30 \text { th day following the date } \\
\text { of cancellation of the state of epidemic emergency or the state of epidemic - depending on which one was the } \\
\text { last in force. cvii } \\
\text { - Automatic extension for work permits, visas and residence cards that expire during the pandemic until } 30 \\
\text { days after the end of the pandemic.cviii } \\
\text { - Eligible seasonal workers are exempt from work permit requirement until } 30 \text { days after end of the } \\
\text { pandemic, provided that they already held a proper work authorization document after March } 13,2020 \text {. cix }\end{array}$ \\
\hline Portugal & International & Receiving & $\begin{array}{l}\text { - Portugal has granted immigrants and asylum seekers whose applications are being processed temporary } \\
\text { residency rights, which gives them access to public services such as national health services and welfare } \\
\text { benefitscx } \\
\text { - Visas or residence permit cards which expired on or after February } 24,2020 \text { are automatically extended } \\
\text { until June } 30,2020 \text {.cxi }\end{array}$ \\
\hline Qatar & International & Receiving & $\begin{array}{l}\text { - Qatar has announced that full salaries will be provided to migrant workers in quarantine or treatment by } \\
\text { employers, and has set aside funds to support companiescxii } \\
\text { - Has said that workers unable to return home if their jobs are terminated will be able to remain "with proper } \\
\text { lodging and food"cxiii } \\
\text { - Online remittances have been introduced to replace exchange houses with companies mandated to educate } \\
\text { workers about online remittance services }\end{array}$ \\
\hline Romania & International & Receiving & $\begin{array}{l}\text { - The work/residence status of foreign workers will not be negatively affected if placed on furlough (technical } \\
\text { unemployment) or temporary reduction of work hours, provided their employment relationship continues. }{ }^{\text {cxiv }}\end{array}$ \\
\hline $\begin{array}{c}\text { Russian } \\
\text { Federation }\end{array}$ & International & Receiving & $\begin{array}{l}\text { - A Presidential Decree was issued to regulate the legal status of foreign nationals for an interim period of three } \\
\text { months; under the Decree, during March } 15 \text { - June } 15 \text { migrant workers are freed from buying work permits, } \\
\text { commonly known as "patents," to legally stay and work in Russiacxv } \\
\text { - Work Permit and Temporary/Permanent Residence Permit holders staying outside Russia for more than six } \\
\text { months will not have their permits cancelled.cxvi } \\
\text { City of Moscow } \\
\text { - The Mayor of Moscow declared that migrants will not be denied medical assistance if they need itcxvii }\end{array}$ \\
\hline
\end{tabular}




\begin{tabular}{|c|c|c|c|}
\hline Saudi Arabia & International & Receiving & 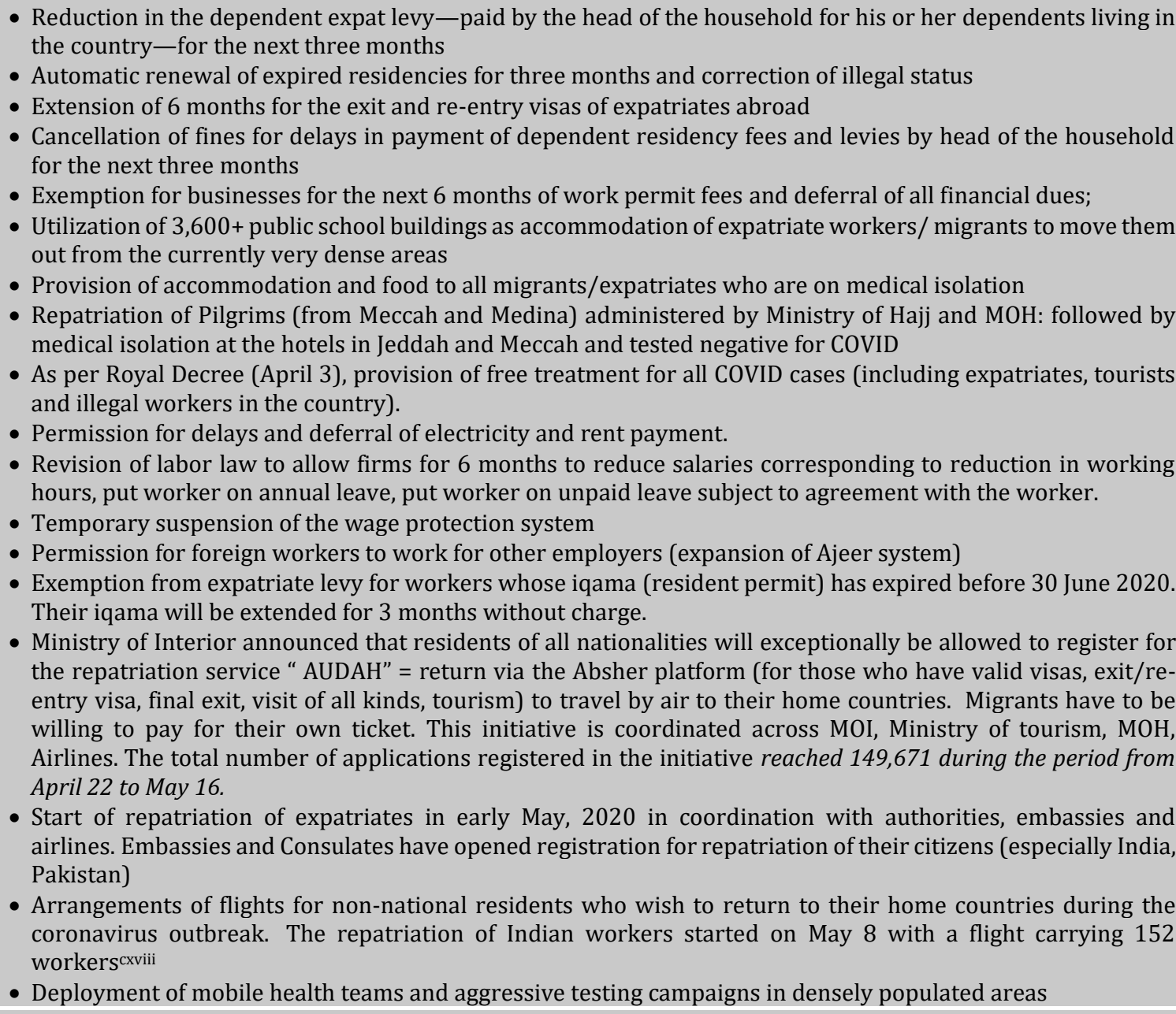 \\
\hline Serbia & International & Receiving & $\begin{array}{l}\text { - Foreign workers' work/residence status is not directly affected by work hours/salary reductions related to } \\
\text { the pandemiccxix }\end{array}$ \\
\hline Singapore & International & Receiving & $\begin{array}{l}\text { - Singapore provided } \$ 35 \text { a day in housing support to assist with employers' costs due to Malaysia-imposed } \\
\text { restrictions preventing frequent commuter workers from returning to Malaysia. The assistance has now } \\
\text { terminated.cxx } \\
\text { - To help ease labor costs, the government announced that monthly Foreign Worker Levy due in April } 2020 \text { will } \\
\text { be waived. The government will also provide employers with a Foreign Worker Levy Rebate of } \$ \$ 750 \text { for each } \\
\text { work permit or S Pass holder, based on previous levies paid in 2020.cxxi }\end{array}$ \\
\hline
\end{tabular}




\begin{tabular}{|c|c|c|c|}
\hline & & & $\begin{array}{l}\text { - Singapore's Ministry of Health announced that all of its migrant workers are to be tested for COVID-19 } \\
\text { before they will be allowed to return to work, a process that is expected to continue until July. cxxii }\end{array}$ \\
\hline $\begin{array}{l}\text { Slovak } \\
\text { Republic }\end{array}$ & International & Receiving & $\begin{array}{l}\text { - Residence statuses due to expire up to one month after the state of emergency are extended for two months } \\
\text { after the state of emergency ends (no date fixed yet)cxxii }\end{array}$ \\
\hline South Africa & International & Receiving & $\begin{array}{l}\text { - Some visa requirements have been waived, particularly deadlines for renewals. Foreign nationals whose } \\
\text { permits are due to expire during the lockdown period will be able to re-apply through a simplified procedure, } \\
\text { once the lockdown has been lifted.cxiv }\end{array}$ \\
\hline Spain & International & Receiving & $\begin{array}{l}\text { - The Spanish government has announced the extension of work permits for foreign workers whose contracts } \\
\text { would expire during the period between the declaration of emergency and June } 30 \text { cxxv } \\
\text { - Regarding companies and institutions that submit applications to the Large Business Unit (UGE) for residence } \\
\text { and work permits for their employees: Applications before March } 18 \text { which have been approved will be } \\
\text { processed and the approvals issued. Applications received before March } 18 \text { and unresolved after } 20 \text { days will } \\
\text { also be approved, and declaratory certificates of approval issued. For refused or archived applications, the } \\
\text { legal timeframe for appeals will be suspended.cxxvi } \\
\text { - The Spanish government has announced that work permits will be provided to young immigrants who arrived } \\
\text { to Spain as unaccompanied minors who have turned } 18 \text { and have residency permits but not work permits cxxvii }\end{array}$ \\
\hline Sri Lanka & International & Sending & $\begin{array}{l}\text { - To help its overseas migrant workers deal with the coronavirus, Sri Lanka's Ministry of Foreign Relations has } \\
\text { launched an online portal where citizens can voice their concerns cxxviii } \\
\text { - After starting its program of repatriation of Sri Lankan students stranded in foreign countries, in early May } \\
\text { the Government approved a cabinet paper focused on the repatriation of migrant workers abroad in } \\
\text { vulnerable conditions. The Cabinet Paper also cover two other important points: first, the need to ensure } \\
\text { that local quarantine facilities are reserved for those coming who can't afford to go to quarantine in Hotels; } \\
\text { second, the importance of continued Diplomatic representation to sustain the large number of migrant } \\
\text { workers in their current places of domicile. cxix } \\
\text { - Has exempted inward remittances from certain regulations and taxescxxx }\end{array}$ \\
\hline Sweden & International & Receiving & $\begin{array}{l}\text { - Reduced hours of layoffs due to the coronavirus do not affect work permit validity if the reduced income is in } \\
\text { line with collective bargaining agreements }\end{array}$ \\
\hline \multirow[t]{2}{*}{ Thailand } & \multirow[t]{2}{*}{ International } & Sending & $\begin{array}{l}\text { - Thailand has just initiated a multi-prong package for Thai workers forced to return from Korea due to the } \\
\text { outbreak. This includes: } \\
\text { Those who are members of Overseas Workers Fund will be entitled to THB15,000 compensation (also } \\
\text { available to member workers who return from other countries that have announced a Covid-19 } \\
\text { outbreak); } \\
\text { The Thai Ministry of Labor will coordinate with labor offices Korea to make sure that Thai laborers } \\
\text { receive pending wages and benefits (the Department of Employment has identified over 81,562 domestic } \\
\text { jobs for Thai laborers returning from overseas) }\end{array}$ \\
\hline & & Receiving & $\begin{array}{l}\text { - Legal foreign workers who registered under article } 33 \text { of social security act, they will receive all benefits. In } \\
\text { the case that the business closes, they will receive } 62 \% \text { of their pay but not exceeding } 90 \text { days. Registered }\end{array}$ \\
\hline
\end{tabular}




\begin{tabular}{|c|c|c|c|}
\hline & & & $\begin{array}{l}\text { workers, including migrants, are also entitled to severance pay if they are terminated.cxxxii They also receive } \\
\text { medical care for check-up and treatment under this article. } \\
\text { On } 15 \text { April, } 2020 \text {, the Thai Government announced a blank extension for the country's migrant workers, } \\
\text { who will be permitted to stay until November } 30 \text { and be exempted from overstay penaltiescxxxiii. } \\
\text { - Other visa relief measures were also announced for non-nationals, including automatic stays for border pass } \\
\text { holders until borders with Cambodia, Lao PDR, and Myanmar are reopened.cxxiv }\end{array}$ \\
\hline & Internal & - & - Providing a cash transfer to informal and self-employed workers \\
\hline Uganda & International & Receiving & $\begin{array}{l}\text { - Usual fines applied to visa overstayers have been waived for permits expiring during the lockdown } \\
\text { period.cxxxv }\end{array}$ \\
\hline \multirow[t]{2}{*}{$\begin{array}{c}\text { United Arab } \\
\text { Emirates }\end{array}$} & \multirow[t]{2}{*}{ International } & Receiving & $\begin{array}{l}\text { - Firms are encouraged to consider alternative methods to reduce costs other than workers' termination. A } \\
\text { new decree allows firms to provide migrant workers, subject to mutual agreement, with the alternative of } \\
\text { working remotely, taking paid leave, unpaid leave, temporary or permanent reduction in salaries. } \\
\text { - Firms can register workers on a job matching virtual platform in case workers are terminated. } \\
\text { - Employers must pay housing and other allowances until the worker finds another job or leaves the country. } \\
\text { Employers also need to pay the end of service benefits. On housing, Abu Dhabi suspended all rental property } \\
\text { eviction cases, and deferred collection of rent payments and service fees for tenants. Dubai also suspended } \\
\text { rental property eviction cases. } \\
\text { - Extension of residence permits and visas until December } 2020 \\
\text { - Issuance of instructions to facilitate the recruitment of migrant workers through the creation of a 'virtual } \\
\text { labor market' (under the Ministry of Human Resources and Emiratisation) to facilitate the provision of job } \\
\text { opportunities for suspended employees } \\
\text { - Provision of essential food supplies to } 12,000 \text { vulnerable families and foreign workers. } \\
\text { - Partial amnesty for visa violators recently implemented, whereby they can exit the country without paying } \\
\text { any penaltiescxxxvi }\end{array}$ \\
\hline & & Sending & $\begin{array}{l}\text { - The Government announced the extension of the "Tawajudi" service to include residents stranded abroad who } \\
\text { hold valid UAE residence visa to facilitate their safe return to the country. Tawajudi Institute services usually } \\
\text { offer assistance to UAE citizens who find themselves in an emergency situation when they are abroad. By } \\
\text { expanding Tawajudi services to include valid residency holders as well as UAE citizens, the UAE is ensuring } \\
\text { the health and safety of UAE's people by putting systems into place that will ensure that people will be safely } \\
\text { returned to the UAE should the situation call for repatriation.cxxvii }\end{array}$ \\
\hline $\begin{array}{c}\text { United } \\
\text { Kingdom }\end{array}$ & International & Receiving & $\begin{array}{l}\text { - The United Kingdom has extended visas until May 31, } 2020 \text { for those whose leave expired on or after January } \\
24,2020 \text { and are in the United Kingdom because of travel restrictions or self-isolation related to COVID- } \\
\text { 19cxxxvii } \\
\text { - Automatically extended the visas of foreign doctors for one yearcxxxix } \\
\text { For all overseas visitors, including anyone living in the UK without permission: No charges apply to testing } \\
\text { for COVID-19. The same is true of most other infectious diseases. No immigration checks are required for } \\
\text { overseas visitors that are known to be only undergoing testing or treatment for COVID-19.cxl } \\
\text { - As part of arrangements to avoid redundancies, the UK government has confirmed that employers of Tier } 2 \\
\text { or Tier } 5 \text { workers may reduce their salaries to the amounts payable under the provisions of the economic } \\
\text { stimulus package, i.e. } 80 \% \text { of the normal salary, or GBP 2,500 per month, whichever is lower. This includes } \\
\text { where the resulting salary is below the normal minimum for the occupation or visa category. Reductions } \\
\text { must be part of a company-wide policy to avoid redundancies and in which all workers are treated the same, }\end{array}$ \\
\hline
\end{tabular}




\begin{tabular}{|c|c|c|c|}
\hline & & & $\begin{array}{l}\text { and the pay of sponsored workers must return to at least previous levels once these arrangements have } \\
\text { ended.cxli }\end{array}$ \\
\hline United States & International & Receiving & 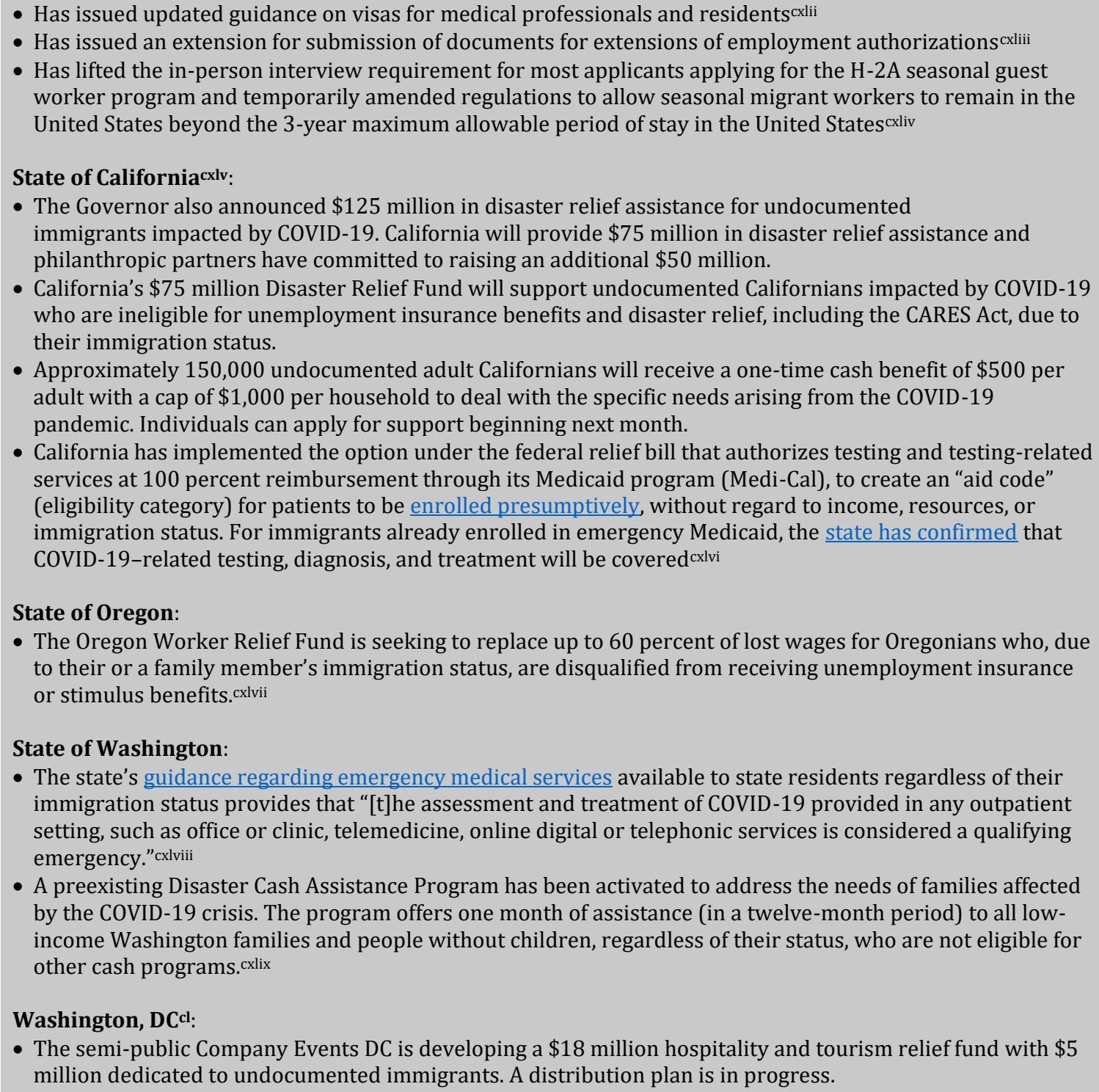 \\
\hline
\end{tabular}




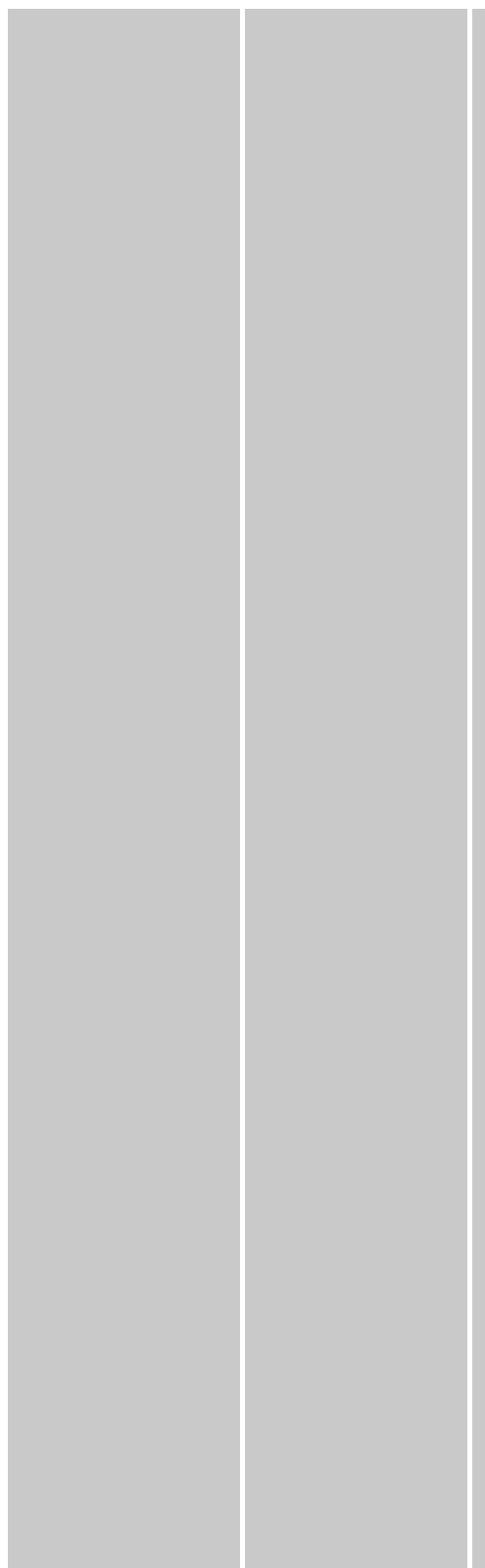

\section{City of Austincli}

- Approved a \$15 million relief fund that includes funds for one-time cash payments and may prioritize people, including undocumented migrants, who do not quality for assistance from the federal government

\section{City of Boston}

- A \$3 million fund was established to assist city residents, regardless of their immigration status, who are at risk of losing rental housing due to COVID-19. clii

\section{City of Chicagocliii.}

- The Mayor signed an executive order explicitly ensuring that all benefits, opportunities, and services provided or administered by the City of Chicago are accessible to all residents, regardless of birth country or current citizenship status.

- To address the challenges that the COVID-19 pandemic poses to Chicago's communities, including its immigrant community, the City of Chicago has implemented numerous programs to aid all residents during this extraordinarily challenging time, including:

- Establishing the COVID-19 Housing Assistance Grant program, which provides disaster relief aid for the housing costs faced by individuals and families impacted by the COVID-19 pandemic;

- Offering online Enrichment Learning Resources through Chicago Public Schools for all students at all levels, so that each student, regardless of immigration status, can continue to pursue a top-notch education; and

- Starting a \$100 million Chicago Small Business Resiliency Fund to provide small businesses with disaster relief cash flow during the COVID-19 pandemic, which is available to any entrepreneur, including immigrant business owners.

\section{City of Minneapoliscliv}

- Create a $\$ 5$ million forgivable loan program to assist renters and small businesses that is open to people regardless of immigration or documentation status; includes up to $\$ 1,500$ for emergency housing assistance to households that have lost income because of the coronavirus and make less than 30 percent of the area median income

\section{City of New York}

- A $\$ 20$ million emergency relief fund, funded by the Open Society Foundations, was announced to provide one-time emergency relief payments to immigrant families, including undocumented workers, through community-based organizations and worker centers clv

- The New York Department of Health issued a Medicaid Update clarifying that coverage of COVID-19 testing, evaluation, and treatment are included under state emergency Medicaid for those whose income is 138 percent or less of the federal poverty level irrespective of migration statusclvi

City of Seattleclvii

- $\$ 5$ will be dispersed to 6,250 families through grocery vouchers. Priority is given to vulnerable populations including migrants. An additional $\$ 10$ million is in process to expand program 


\begin{tabular}{|c|c|c|c|}
\hline Uzbekistan & International & Receiving & $\begin{array}{l}\text { - Labor market interventions under the } 10 \text { trillion soum Anti-Crisis fund include support for labor migrants } \\
\text { via vocational ad language training }\end{array}$ \\
\hline \multirow{3}{*}{ Vietnam } & \multirow[t]{2}{*}{ International } & Sending & $\begin{array}{l}\text { - Vietnam's National Assembly is debating a revision of the Fund for Overseas Employment Support, in part as } \\
\text { a reaction to the COVID-19 outbreak, that would allow the fund to be spent on preventing risks for laborers } \\
\text { while working abroad and educating workers abroad on laws relevant to them. }{ }^{\text {clviii }}\end{array}$ \\
\hline & & Receiving & $\begin{array}{l}\text { Proposed easing its COVID-19-related restrictions on international entry to allow high-skilled foreign } \\
\text { nationals to enter the country because of a shortage of qualified replacements }{ }^{c l i x}\end{array}$ \\
\hline & Internal & - & - Considering a cash transfer to informal and self-employed workers \\
\hline Zimbabwe & & Sending & - Money transfer agencies allowed to open 3 times per week ${ }^{\mathrm{clx}}$ \\
\hline
\end{tabular}




\section{Endnotes}

i https://www.scmp.com/week-asia/health-environment/article/3079675/coronavirus-singapore-migrantworker-dormitories-still; https://www.nytimes.com/2020/04/13/world/middleeast/persian-gulf-migrantscoronavirus.html

ii https://migrationdataportal.org/themes/migration-data-relevant-covid-19-pandemic

iii https://www.nytimes.com/2020/04/10/world/asia/coronavirus-migrants.html

iv https://www.aljazeera.com/news/2020/04/hundreds-nepalese-stuck-india-border-covid-19-lockdown200401031905310.html

v https://www.nytimes.com/2020/03/27/business/coronavirus-farm-labor-europe.html

vi https://www.ft.com/content/e27a9395-db47-4e7b-b054-3ec6ba4cbba3

vii https://www.ft.com/content/48e0e762-5f40-4804-bbb9-0b84b1dea093

viii https://www.usatoday.com/story/money/business/2020/04/04/coronavirus-tests-americas-foodsupply-agriculture/5096382002/

ix https://www.reuters.com/article/us-health-coronavirus-india-harvests/coronavirus-lockdown-le

x https://migrationdataportal.org/themes/migration-data-relevant-covid-19-pandemic

xi https://www.economist.com/middle-east-and-africa/2020/04/16/covid-stops-many-migrants-sendingmoney-home

xii https://devpolicy.org/border-closures-and-grounded-international-travel-implications-for-pacificseasonal-workers-20200325/

xiii https://www.nytimes.com/2020/03/26/world/asia/afghanistan-iran-coronavirus.html

xiv https://frontiermyanmar.net/en/alarm-as-thousands-of-returning-workers-ignore-quarantine-orders

xv https://www.independent.co.uk/news/world/europe/coronavirus-portugal-migrants-asylum-seekerstreatment-residents-a9431831.html

xvi https://www.iom.int/news/iom-recognizes-efforts-europe-middle-east-protect-all-migrants-accesspublic-health

xvii https://www.aljazeera.com/news/2020/04/qatar-pay-workers-quarantine-full-salaries200401110548709.html

xviii https://www.iom.int/news/iom-recognizes-efforts-europe-middle-east-protect-all-migrants-access-

public-health

xix https://www.mom.gov.sg/covid-19/temporary-housing-support

xx https://www.thestar.com.my/news/nation/2020/04/03/rushing-to-beat-the-deadline

xxi https://www.aljazeera.com/news/2020/04/qatar-pay-workers-quarantine-full-salaries200401110548709.html

xxii https://www.pna.gov.ph/articles/1097814

xxiii https://www.nationthailand.com/news/30383231

xxiv https://economictimes.indiatimes.com/nri/visa-and-immigration/uk-extends-work-visas-for-indian-

foreign-doctors-amid-coronavirus-outbreak/articleshow/74928228.cms

xxv https://global.chinadaily.com.cn/a/202004/02/WS5e853c68a310128217283cce.html

xxvi https://www.ft.com/content/871b6d39-4497-49c5-856c-549cb42e67ce

xxvii https://en.vietnamplus.vn/labour-ministry-seeks-entry-for-nearly-8500-foreign-experts/171016.vnp

xxviii https://blogs.worldbank.org/psd/remittances-times-coronavirus-keep-them-flowing

xxix https://minnesotareformer.com/briefs/minneapolis-creates-5-million-covid-19-relief-fund-available-toundocumented-residents/

xxx https://www.gov.ca.gov/2020/04/15/governor-newsom-announces-new-initiatives-to-supportcalifornia-workers-impacted-by-covid-19/

xxxi https://www.lanacion.com.ar/sociedad/coronavirus-municipios-provincia-buenos-aires-sumaranmedicos-nid2346577

xxxii https://www.natlawreview.com/article/covid-19-australia-travel-bans-and-other-migration-faqs xxxiii https://www.abc.net.au/news/2020-04-22/financial-hardship-package-for-temporary-visa-

holders/12171546

xxxiv https://www.euractiv.com/section/economy-jobs/news/austria-imports-workers-from-bulgariaromania-to-plug-gaps-in-covid-19-care/

xxxv https://www.fragomen.com/file/newcoronavirustablefornewspage526v7pdf 
xxxvi https://www.migrant-rights.org/2020/04/bahrain-announces-amnesty-for-irregular-migrants-andcuts-in-flexi-permit-fees/

xxxvii https://www.ilo.org/wcmsp5/groups/public/---ed protect/---protrav/----

migrant/documents/publication/wcms 743268.pdf

xxxvii https://www.rtbf.be/info/belgique/detail moratoire-sur-les-faillites-d-entreprises-defiscalisation-des-

heures-sup-voici-les-mesures-prises-par-le-kern-elargi?id=10480563

xxxix https://www.covid19healthsystem.org/countries/belgium/countrypage.aspx

xl https://www.fragomen.com/file/newcoronavirustablefornewspage526v7pdf

xli https://www.iom.int/sites/default/files/our work/DMM/IBM/2020/en/covid-19iomissuebriefimmigrationconsularandvisarecommendations.pdf

xlii https://reliefweb.int/sites/reliefweb.int/files/resources/76211 0.pdf

xliii https://reliefweb.int/sites/reliefweb.int/files/resources/76211 0.pdf

xliv https://www.fragomen.com/file/newcoronavirustablefornewspage519v4pdf

xlv https://ici.radio-canada.ca/nouvelle/1672789/fermeture-frontieres-upa-exemption-travailleursetrangers

xlvi https://www.immigration.ca/canadian-employers-must-pay-mandatory-14-day-quarantine-when-hiringtemporary-foreign-workers

xlvii https://www.immigration.ca/canada-opens-applications-for-new-agri-food-immigration-pilot

xlviii https://www.immigration.ca/coronavirus-temporary-workers-can-now-start-new-canada-jobs-in-10-

days

xlix https://www.immigration.ca/prince-edward-island-leverages-pei-pnp-to-support-healthcare-and-

trucking-industries

${ }^{1}$ https://www.immigration.ca/nova-scotia-immigration-targets-nurses-in-new-labour-market-priorities$\underline{\text { draw }}$

${ }^{l i}$ https://www2.gov.bc.ca/gov/content/health/health-drug-coverage/msp/bc-residents/msp-covid-19response

lii https://www.cp24.com/news/ontario-waives-three-month-ohip-waiting-period-1.4861916

liii https://www.educaloi.qc.ca/en/news/covid-19-rights-people-who-are-not-citizens-or-permanentresidents

liv https://www.iom.int/sites/default/files/our work/DMM/IBM/2020/en/covid-19iomissuebriefimmigrationconsularandvisarecommendations.pdf

lv https://www.iom.int/sites/default/files/our work/DMM/IBM/2020/en/covid-19iomissuebriefimmigrationconsularandvisarecommendations.pdf

lvi https://www.iom.int/sites/default/files/our work/DMM/IBM/2020/en/covid-19iomissuebriefimmigrationconsularandvisarecommendations.pdf

lvii https://www.fragomen.com/file/newcoronavirustablefornewspage519v4pdf

lviii https://www.fragomen.com/file/newcoronavirustablefornewspage519v4pdf

lix https://www.iom.int/sites/default/files/our work/DMM/IBM/2020/en/covid-19iomissuebrief-

immigrationconsularandvisarecommendations.pdf

Ix http://www.xinhuanet.com/english/2020-05/06/c 139035914.htm

lxi https://www.fragomen.com/file/newcoronavirustablefornewspage519v4pdf

lxii https://www.fragomen.com/file/newcoronavirustablefornewspage526v7pdf

Ixiii https://www.dgb.de/themen/++co++b8f3388e-6f45-11ea-8f86-52540088cada

lxiv https://www.stmwi.bayern.de/soforthilfe-corona/

lxv https://www.ft.com/content/871b6d39-4497-49c5-856c-549cb42e67ce

lxvi https://www.nds-fluerat.org/wp-content/uploads/2020/04/Erlass-MI-Nds-Beschftgng-Ernte 06-042020.pdf

lxvii https://www.nds-fluerat.org/wp-content/uploads/2020/03/Umsetzung-des-\%C2\%A7-1a-AsylbLGSARS-CoV-2-Pandemie.pdf

Ixviii https://www.euractiv.com/section/coronavirus/news/how-immigration-strengthens-the-germanhealthcare-system/

lxix https://www.fragomen.com/file/newcoronavirustablefornewspage519v4pdf

lxx https://www.fragomen.com/file/newcoronavirustablefornewspage519v4pdf

lxxi https://www.info.gov.hk/gia/general/202002/04/P2020020400547.htm 
lxxii http://documents.worldbank.org/curated/en/448321588971503966/pdf/Social-Protection-and-JobsResponses-to-COVID-19-A-Real-Time-Review-of-Country-Measures-May-8-2020.pdf

lxxii https://www.wsj.com/articles/india-prepares-large-scale-repatriation-of-workers-stranded-by-

pandemic-11588620671

Ixxiv https://www.arabnews.com/node/1671866/saudi-arabia

Ixxv https://www.aljazeera.com/news/2020/05/outrage-india-asks-migrants-pay-train-journey200504103208273.html

lxxvi https://www.worldbank.org/en/news/press-release/2020/05/13/world-bank-covid-coronavirus-indiaprotect-poor?cid=SHR SitesShareFB EN EXT

lxxvii https://www.news18.com/news/india/govt-changes-rules-to-help-migrant-workers-amid-covid-19-

lockdown-state-disaster-funds-to-be-used-for-providing-food-shelter-2555037.html

lxxviii https://www.mrci.ie/2020/03/30/covid19-social-welfare-supports-for-workers/

lxxix http://www.inis.gov.ie/en/INIS/Pages/COVID-19-updates-and-announcements

Ixxx https://coronavirus.jumamap.com/en/lavoro/

Ixxi https://coronavirus.jumamap.com/en/asilo-e-immigrazione/

lxxxii https://coronavirus.jumamap.com/en/aiuti-sociali/

Ixxxiii https://coronavirus.jumamap.com/en/aiuti-sociali/

lxxxiv https://www.aljazeera.com/news/2020/05/thousands-undocumented-migrants-italian-work-permits200513181704599.html

Ixxx https://www.coe.int/en/web/interculturalcities/covid-19-special-page\#\{\%2262433518\%22:[5]\}

lxxxvi https://asia.nikkei.com/Spotlight/Coronavirus/Abe-adopts-universal-930-handout-as-walls-close-in;

and https://metropolisjapan.com/covid-19-financial-relief/

lxxxvii https://www.arabnews.com/node/1665221/middle-east

lxxxviii https://www.ilo.org/wcmsp5/groups/public/---ed protect/---protrav/---

migrant/documents/publication/wcms 743268.pdf

Ixxix https://www.fragomen.com/file/newcoronavirustablefornewspage519v4pdf

xc https://www.thedailystar.net/city/news/special-amnesty-undocumented-workers-kuwait-4300-

bangladeshis-set-return-1894003

xci https://www.theedgemarkets.com/article/pm-foreign-worker-levy-cut-25-those-permit-ending-dec-31-

2020-not-applicable-domestic

xcii https://www.malaymail.com/news/malaysia/2020/04/22/foreign-workers-can-apply-online-to-renew-

temporary-employment-visit-pass-s/1859317

xciii https://www.iom.int/sites/default/files/our work/DMM/IBM/2020/en/covid-19iomissuebrief-

immigrationconsularandvisarecommendations.pdf

xciv http://documents.worldbank.org/curated/en/448321588971503966/pdf/Social-Protection-and-Jobs-

Responses-to-COVID-19-A-Real-Time-Review-of-Country-Measures-May-8-2020.pdf

xcv https://reliefweb.int/report/myanmar/iom-myanmar-covid-19-response-situation-report-3-1-may-2020

xcvi https://reliefweb.int/report/myanmar/iom-myanmar-covid-19-response-situation-report-3-1-may-2020

xcvii https://frontiermyanmar.net/en/workers-mothers-and-elderly-to-benefit-from-25m-in-covid-19-

foreign-aid

xcviii https://kathmandupost.com/national/2020/05/05/government-considers-bringing-back-nepali-

migrant-workers-from-covid-19-affected-countries

xcix https://devpolicy.org/covid-19-rse-responses-challenges-and-logistics-20200415/

c https://www.fragomen.com/file/newcoronavirustablefornewspage519v4pdf

ci https://www.fragomen.com/file/newcoronavirustablefornewspage526v7pdf

cii https://www.iom.int/news/iom-panama-prepare-covid-19-response-2500-migrants-stranded-borders

ciii https://www.eldiario.es/desalambre/COVID-19-migracion-irregular-Panama-EEUU 0 1014199695.html

civ http://reporting.unhcr.org/sites/default/files/UNHCR\%20NCA\%20situation\%20Fact\%20Sheet $\% 20$ \%20March\%202020 0.pdf

${ }^{c v}$ https://reliefweb.int/sites/reliefweb.int/files/resources/76211_0.pdf

cvi https://www.rappler.com/nation/261714-house-panel-eyes-additional-aid-ofws-coronavirus-

pandemic?utm medium=Social\&utm campaign=Echobox\&utm source=Facebook\&fbclid=IwAR0hKFYRVsefM

N1jAcBzXcmQ7WbRub2Q2Idt-mDfDVnTIxKJHy8SX9b qFw\#Echobox=1590141786

cvii https://udsc.gov.pl/en/coronavirus-outbreak-another-solutions-dedicated-to-foreigners/

cviii https://www.fragomen.com/file/newcoronavirustablefornewspage519v4pdf 
cix https://www.fragomen.com/file/newcoronavirustablefornewspage526v7pdf

cx https://www.reuters.com/article/us-health-coronavirus-portugal/portugal-to-treat-migrants-asresidents-during-coronavirus-crisis-idUSKBN21F0N7

cxi https://www.fragomen.com/file/newcoronavirustablefornewspage519v4pdf

cxii https://www.aljazeera.com/news/2020/04/qatar-pay-workers-quarantine-full-salaries200401110548709.html

cxiii https://www.aljazeera.com/news/2020/04/qatar-pay-workers-quarantine-full-salaries200401110548709.html

cxiv https://www.fragomen.com/file/newcoronavirustablefornewspage519v4pdf

cxv http://kremlin.ru/acts/news/63216

cxvi $\underline{\text { https://www.fragomen.com/file/newcoronavirustablefornewspage519v4pdf }}$

cxvii https://www.interfax.ru/moscow/706926

cxviii https://www.arabnews.com/node/1671866/saudi-arabia

cxix https://www.fragomen.com/file/newcoronavirustablefornewspage519v4pdf

cxx https://www.thestar.com.my/news/nation/2020/04/03/rushing-to-beat-the-deadline

cxxi https://mothership.sg/2020/04/foreign-worker-levy-waived/

cxxii https://www.youtube.com/watch?v=6v8QvVo1kT8

cxxiii https://www.fragomen.com/file/newcoronavirustablefornewspage519v4pdf

cxxiv https://www.iom.int/sites/default/files/our work/DMM/IBM/2020/en/covid-19iomissuebrief-

immigrationconsularandvisarecommendations.pdf

cxxv https://www.fragomen.com/file/newcoronavirustablefornewspage519v4pdf

cxxvi https://www.fragomen.com/file/newcoronavirustablefornewspage519v4pdf

cxxvii https://elpais.com/economia/2020-04-07/el-gobierno-limita-los-casos-de-inmigrantes-que-tendran-

autorizacion-de-trabajo-para-incorporarse-a-las-campanas-agricolas.html

cxxviii https://www.arabnews.com/node/1649671/world

cxxix https://www.mfa.gov.lk/media-release-7-5-2020/

cxxx https://www.imf.org/en/Topics/imf-and-covid19/Policy-Responses-to-COVID-19

cxxi https://www.fragomen.com/file/newcoronavirustablefornewspage519v4pdf

cxxxii https://www.ilo.org/asia/publications/issue-briefs/WCMS 741920/lang--en/index.htm

cxxxii https://thethaiger.com/coronavirus/migrant-workers-in-thailand-can-now-stay-until-november-30

cxxxiv https://www.ilo.org/asia/publications/issue-briefs/WCMS 741920/lang--en/index.htm

cxxxv https://www.iom.int/sites/default/files/our work/DMM/IBM/2020/en/covid-19iomissuebrief-

immigrationconsularandvisarecommendations.pdf

cxxxvi https://www.khaleejtimes.com/uae/abu-dhabi/coronavirus-3-month-grace-for-uae-visa-violators-whowant-to-leave-the-country--

cxxxvii https://www.uae-voice.net/uae-emergency-provisions-tawajudi-service/

cxxxviii https://www.iom.int/news/iom-recognizes-efforts-europe-middle-east-protect-all-migrants-access-

public-health

cxxxix https://economictimes.indiatimes.com/nri/visa-and-immigration/uk-extends-work-visas-for-indian-

foreign-doctors-amid-coronavirus-outbreak/articleshow/74928228.cms

cxl https://migrantinfohub.org.uk/news-and-updates/27042020-free-covid-19-healthcare-is-accessible-tomigrants-translated-in-40-languages

cxli https://www.fragomen.com/file/newcoronavirustablefornewspage526v7pdf

cxlii https://travel.state.gov/content/travel/en/News/visas-news/update-on-h-and-j-visas-for-medical-

professionals.html

cxliii https://ogletree.com/insights/due-to-covid-19-uscis-extends-notice-deadlines-will-accept-previously-

submitted-biometrics-for-employment-authorization-extensions/

cxliv https://www.uscis.gov/working-united-states/temporary-workers/h-2a-temporary-agricultural-

workers; and https://www.latimes.com/business/story/2020-03-27/state-department-eases-requirements-

for-h2a-visa

cxlv https://www.gov.ca.gov/2020/04/15/governor-newsom-announces-new-initiatives-to-support-

california-workers-impacted-by-covid-19/

cxlvi https://www.nilc.org/resources-covid19-crisis-and-consequences/covid-19-shared-crisis-shared-

solutions/\#testing 
cxlvii https://www.nilc.org/resources-covid19-crisis-and-consequences/covid-19-shared-crisis-sharedsolutions/\#testing

cxlviii https://www.nilc.org/resources-covid19-crisis-and-consequences/covid-19-shared-crisis-sharedsolutions/\#testing

cxlix https://www.nilc.org/resources-covid19-crisis-and-consequences/covid-19-shared-crisis-sharedsolutions/\#testing

${ }^{c l}$ https://localprogress.org/wp-content/uploads/2020/04/State-and-Local-Covid-Response-Funds4.17.20.pdf

cli https://www.kut.org/post/big-deal-austin-approves-15-million-relief-fund-includes-cash-assistance$\underline{\text { residents }}$

clii https://www.nilc.org/resources-covid19-crisis-and-consequences/covid-19-shared-crisis-sharedsolutions/\#testing

cliihttps://www.chicago.gov/city/en/depts/mayor/press_room/press releases/2020/april/EOImmigrantRef ugeeProtection.html

cliv https://minnesotareformer.com/briefs/minneapolis-creates-5-million-covid-19-relief-fund-available-toundocumented-residents/; http://minneapolismn.gov/coronavirus/gap-funding

clv https://www1.nyc.gov/office-of-the-mayor/news/262-20/mayor-de-blasio-new-york-city-covid-19immigrant-emergency-relief-program-open

clvi https://www.nilc.org/resources-covid19-crisis-and-consequences/covid-19-shared-crisis-sharedsolutions/\#testing

clvii https://localprogress.org/wp-content/uploads/2020/04/State-and-Local-Covid-Response-Funds4.17.20.pdf

clviii https://vietnamnews.vn/politics-laws/715457/molisa-aims-to-alter-uses-of-overseas-employmentfund.html

clix https://en.vietnamplus.vn/labour-ministry-seeks-entry-for-nearly-8500-foreign-experts/171016.vnp

clx https://www.businesslive.co.za/bd/world/africa/2020-04-07-zimbabwe-eases-lockdown-for-diasporapayouts-and-fresh-market-produce/ 